\title{
Design, Development, and Analysis of a Densely Packed 500x Concentrating Photovoltaic Cell Assembly on Insulated Metal Substrate
}

\author{
Leonardo Micheli, ${ }^{1}$ Nabin Sarmah, ${ }^{2}$ K. S. Reddy, ${ }^{3}$ Xichun Luo, ${ }^{4}$ and Tapas K. Mallick ${ }^{1}$ \\ ${ }^{1}$ Environment and Sustainability Institute, University of Exeter, Penryn Campus, Penryn, Cornwall TR10 9FE, UK \\ ${ }^{2}$ Department of Energy, Tezpur University, Tezpur, Assam 784 028, India \\ ${ }^{3}$ Heat Transfer and Thermal Power Laboratory, Department of Mechanical Engineering, Indian Institute of Technology Madras, \\ Chennai 600 036, India \\ ${ }^{4}$ Department of Design, Manufacture and Engineering Management, Faculty of Engineering, University of Strathclyde, \\ Glasgow G1 1XQ, UK
}

Correspondence should be addressed to Tapas K. Mallick; t.k.mallick@exeter.ac.uk

Received 14 May 2015; Accepted 28 July 2015

Academic Editor: Cheuk-Lam Ho

Copyright ( 2015 Leonardo Micheli et al. This is an open access article distributed under the Creative Commons Attribution License, which permits unrestricted use, distribution, and reproduction in any medium, provided the original work is properly cited.

\begin{abstract}
The paper presents a novel densely packed assembly for high concentrating photovoltaic applications, designed to fit $125 \mathrm{x}$ primary and $4 \mathrm{x}$ secondary reflective optics. This assembly can accommodate 144 multijunction cells and is one of the most populated modules presented so far. Based on the thermal simulation results, an aluminum-based insulated metal substrate has been used as baseplate; this technology is commonly exploited for Light Emitting Diode applications, due to its optimal thermal management. The original outline of the conductive copper layer has been developed to minimize Joule losses by reducing the number of interconnections among the cells in series. Oversized Schottky diodes have been employed for bypassing purposes. The whole design fits the IPC-2221 requirements. The plate has been manufactured using standard electronic processes and then characterized through an indoor test and the results are here presented and commented on. The assembly achieves a fill factor above $80 \%$ and an efficiency of $29.4 \%$ at $500 x$, less than $2 \%$ lower than that of a single cell commercial receiver. The novel design of the conductive pattern is conceived to decrease the power losses and the deployment of an insulated metal substrate represents an improvement towards the awaited cost-cutting for high concentrating photovoltaic technologies.
\end{abstract}

\section{Introduction}

The basic idea behind the Concentrating Photovoltaics (CPV) is to reduce the cost of photovoltaic plants by replacing some of the expensive semiconductor material with a cheaper reflective or refractive material (such as a mirror or a lens) $[1,2]$. This way the irradiance can be raised up to a few thousand times. The use of CPV contributes to reducing the materials and energy required for the fabrication of the PV cells [3], introducing a substantial benefit for the environment. Moreover, by decreasing the amount of photovoltaic material, the exploitation of more expensive and more efficient multijunction solar cells becomes cost-effective $[4,5]$.
These cells are particularly beneficial in systems achieving concentrations higher than 300 suns (high concentrating photovoltaic, HCPV) [6]. Multijunction cells are made of more than one semiconductive layer and those commercially available grant efficiencies between 37 and $42 \%$ [6], whereas a record efficiency of $46.0 \%$ has already been announced [7]. Multijunction cells are considered to be able to reach over $50 \%$ efficiencies in future terrestrial applications [8].

The IEEE defines a CPV receiver as "an assembly of one or more PV cells that accepts concentrated sunlight and incorporate the means for thermal and electric energy removal" [9]. The surface mounted components (such as cells, interconnectors, and diodes) are installed on the top 
surface of a conductive layer. The electrically conductive layer is usually not self-supporting so it has to be placed over a dielectric surface that provides both mechanical support and electric insulation. Copper is the most convenient conductive material, due to its good compromise between cost and performance. A printed circuit board (PCB) is a laminated material bonded with heat cured flame retardant epoxy resin and clad on either one or both sides with copper. PCBs are widely used in electronics, because of their high flexibility and relatively low cost. The laminate materials are primarily chosen to grant a structural strength to the board, but electrical properties (i.e., dielectric constant and electrical strength) and environmental properties (thermal expansion, glass transition) also have to be considered. Usually the laminated material is a low thermal conductive fiberglass, but it can be replaced with a metal baseplate. This way, the thermal management of the system can be enhanced and the board is referred to as an insulated metal substrate (IMS). IMSs have been developed for being used in LED (Light Emitting Diodes) applications, and they show a heat transfer management similar to that needed by high concentrating photovoltaic technologies [10]. IMSs are considered to be the best choice in applications where specific designs are needed, no matter the required quantity [11]. For these reasons, HCPV assembly manufacturers' interest in IMS technology is increasing [10, 12-14]. Mabille and his group [12] have demonstrated that when exposed to accelerated aging tests, IMSs behave similarly to the direct bonded copper (DBC) boards, the most expensive substrates $[15,16]$ and the most widely used substrates in HCPV applications to date [17-20].

Despite the fact that a number of HCPV modules have been presented in the literature [21-23], no reference has been found detailing their designing and development. This paper focuses instead on a new insulated metal substrate-based 144cell assembly for 500x HCPV applications. The aim of the work has been to produce an efficient and innovative receiver, by introducing an original, scalable, low-resistance pattern for the conductive layer and by enhancing the thermal management through analytical investigations and simulations. After a brief description of the whole HCPV system where the presented assembly will be installed, the selection of the components is described. Particular care is given to prove the reliability of the substrate. Following, the design of the electrical circuitry is described and the predictions on the electrical losses are also reported. In conclusion, the results of the indoor characterization are detailed.

\section{System and Components}

2.1. The Concentrating Photovoltaic System's Configuration. This work is carried out as part of the BioCPV project [24]. The objective of the project is to develop and to integrate highly efficient solar, biomass, and hydrogen energy technologies to produce noninterrupting power supplies to the rural communities. The assembly presented in this paper is a component to be used in the eight 500x HCPV units designed for this project. Each HCPV unit counts a primary concentrator and a receiver, as represented in Figure 1. The receiver consists of the reported 144-cell assembly, a $4 \mathrm{x}$ secondary concentrator and an active cooling system. The primary $125 \mathrm{x}$ and the secondary $4 \mathrm{x}$ optics result in an overall geometric concentration of 500x: a summary of the concentrator specifications is reported in Table 1.

The $125 \mathrm{x}$ primary concentrator is a parabolic dish with square opening and is made up of four sections to achieve an entry aperture area of $9 \mathrm{~m}^{2}$. The parabola has a focal length of $3.37 \mathrm{~m}$ and is truncated considering a rim angle of $20^{\circ}$. The $3 \mathrm{~m} \times 3 \mathrm{~m}$ primary reflector focuses the light onto a $26.8 \mathrm{~cm}$ $\times 26.8 \mathrm{~cm}$ surface of the receiver. The secondary concentrator is made of 144 three-dimensional compound parabolic concentrators (CPCs) with a square $2 \mathrm{~cm} \times 2 \mathrm{~cm}$ entrance aperture and a square $1 \mathrm{~cm} \times 1 \mathrm{~cm}$ exit aperture. The CPCs are arranged in a $12 \times 12$ array and each CPC reflects the light on a single solar cell. A $10 \mathrm{~mm}$ length homogenizer is placed at the exit of each CPC in order to uniform the irradiation on the cells. In Figure 2, the cross-sectional view of a 12$\mathrm{CPC}$ array and the cross-sectional view of a single CPC with homogenizer are presented.

Each plate is equipped with 144 cells and is rated at $2.6 \mathrm{~kW}_{\mathrm{p}}$ under standard test conditions at $500 \mathrm{x}$. A continuous tracking system allows the plates to follow the Sun and the cells to work at their maximum power point. An active, water-based cooling system is being developed to control the temperature of each receiver of the plant [25].

\subsection{Components}

2.2.1. Solar Cells. A set of $3 \mathrm{C} 40$ cells, provided by AZUR SPACE [26], is used in this application. These devices are $1 \mathrm{~cm}^{2}$ sized $\mathrm{GaInP} / \mathrm{GaAs} / \mathrm{Ge}$ cells with efficiencies up to $37.2 \%$ at 500x, optimized to work between 200x and 800x. These cells are designed to generate a $6.587 \mathrm{~A}$ short-circuit current at $500 \mathrm{x}$, with an open circuit voltage of $3.170 \mathrm{~V}$. At their maximum power point they are expected to work at $18.6 \mathrm{~W}$. The active area sizes are $10 \mathrm{~mm} \times 10 \mathrm{~mm}$. Two $0.45 \mathrm{~mm}$ width $\mathrm{Au} / \mathrm{Ag}$ finished tabs are used as negative pole and are placed on the front edges of the cell: in the ideal case, the current generated is equally distributed between them. The whole back of the cell works as positive pole.

2.2.2. Bypass Diodes. Bypass diodes are essential in any PV applications to reduce the power losses from a series when at least one cell is shadowed and, at the same time, to prevent damages to the shaded cell itself [27]. In regular operation, the diode is reverse-biased and, in this conditions, only a small amount of leakage current flows through it. The device turns on when the cell is shaded and, then, the current bypasses the cell, which would act as an impedance and flows through the low-resistance diode.

In concentrating photovoltaic systems, it has been demonstrated that the installation of one bypass diode per cell maximizes the performances [28]: this configuration is then applied to improve the outputs of the presented plate. The Vishay V10P45S Schottky Rectifier is used in this assembly as it appears to be the best compromise between dimensions and performance. Schottky diodes are usually employed as bypass devices for multijunction cells: they have a lower forward voltage drop and, therefore, lower losses and lower 


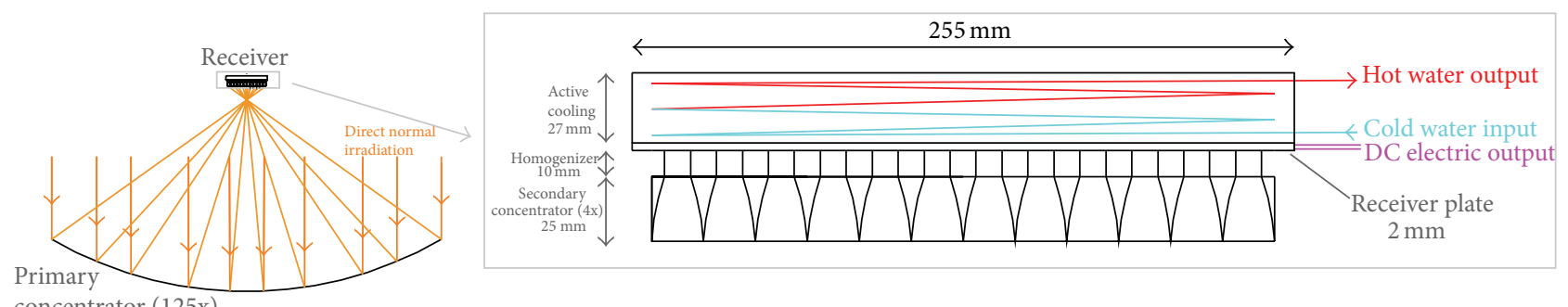

FIGURE 1: Schematic of the system configuration and particular of the receiver.

TABLE 1: Concentrator specifications.

\begin{tabular}{lccc}
\hline \multicolumn{2}{c}{ Primary concentrator } & & \multicolumn{2}{c}{ Secondary concentrator } \\
\hline Geometric concentration ratio & $125 \mathrm{x}$ & Geometric concentration ratio & $4 \mathrm{x}$ \\
Aperture area & $3 \mathrm{~m} \times 3 \mathrm{~m}$ & Cell side aperture area & $10 \mathrm{~mm} \times 10 \mathrm{~mm}$ \\
Rim angle & $20^{\circ}$ & Acceptance angle & $30^{\circ}$ \\
Focal length $(f)$ & $3.37 \mathrm{~m}$ & Length of CPC & $25 \mathrm{~mm}$ \\
$f / d$ ratio & 0.794 & Length of homogenizer & $10 \mathrm{~mm}$ \\
\hline
\end{tabular}

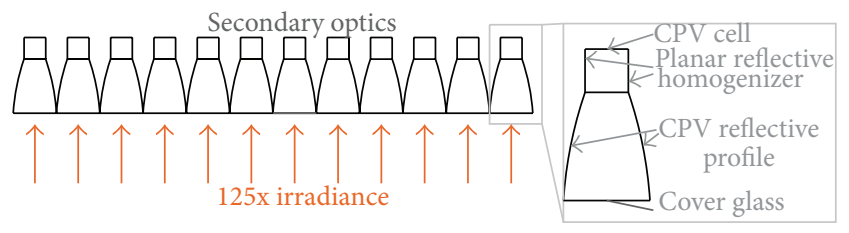

FIGURE 2: Cross-sectional view of the secondary optics.

temperature while in bypass operation than the one of the silicon diodes. Their application is commonly considered practical, economical, and efficient [29]. The diodes are usually oversized to reduce the voltage drops and to reduce the risk of breakage: diodes can easily break when working closer to the maximum rating [30]. A safety factor of at least 1.5 is usually applied (Table 2) from companies in their commercial assemblies. In some application, safety factors can rise up to 10 to achieve a most conservative approach [30].

Taking into account the cell's short-circuit current in the presented scheme $(6.587 \mathrm{~A})$, a $10 \mathrm{~A}$ Schottky diode grants an acceptable safety factor of 1.52 . The peak repetitive reverse voltage is always higher than the cell voltage, even when a conservative safety factor is applied: the cell voltage is less than the $75 \%$ of the peak repetitive reverse voltage. Using two 10 A diodes would have enhanced the safety factor, but there is no space available to allocate them. The diodes applied in the systems are surface-mounted technologies, since they are cheaper than the discrete ones because they do not require any predrilled holes on the board [32].

\section{The Substrate}

The HCPV receivers are designed to maximize the extraction of electrical energy, to enhance the transfer of thermal energy, and to assure an adequate mechanical support. The choice of the geometry and the selection of the materials depend on many factors, such as the concentration and the cost, as well as the thermal management. In this case, the thermal behaviour of the substrate is taken into account: all the incoming energy that is not converted by the cells becomes heat and contribute to increasing the cell temperature. The PV cells are negatively affected by the increase in temperature, which cause drops in electrical efficiency and can lead to mechanical failures.

In this application, an active cooling is developed to dissipate the waste heat produced by the cell: the cell assembly is expected to be designed to optimize the heat transfer from the cell to the cooler. The most of the waste heat is removed from the cell by conduction [33]: the order and the properties of the materials of the substrate have to be opportunely designed to enhance the heat transfer towards the cooling system. For this reason, the conductive heat transfer of the cell assembly is modelled using the COMSOL's "Heat Transfer in Solids" module, in order to predict the thermal behaviour of the system. The equations used in the simulation are reported in the next paragraph.

3.1. The Thermal Model: Equations and Conditions. The stationary pure conductive heat transfer equation is used to model the heat exchange between solids. The heat flux depends on the conductivity of the material $(k)$ and on the temperature gradient between the opposite surfaces $(\nabla T)$. The conduction heat flux vector $(\mathbf{q})$ can be written as follows [34]:

$$
\mathbf{q}=-k \cdot \nabla T
$$

The heat transfer in solids can be expressed through Fourier's law $[34,35]$ :

$$
\rho_{D} \cdot c_{p} \cdot \frac{\partial T}{\partial t}=Q_{v}^{\prime}+k \cdot \nabla^{2} T
$$

where $\rho_{D}$ is the density, $c_{p}$ the specific heat capacity, $t$ the time, and $Q_{v}^{\prime}$ the volumetric rate of heat generated. $\nabla^{2}$ is the 
TABLE 2: Comparison of the safety factors used by HCPV industries and in the developed system.

\begin{tabular}{|c|c|c|c|c|c|c|}
\hline Company & $\begin{array}{l}\text { Cell dimensions } \\
{[\mathrm{mm} \times \mathrm{mm}]}\end{array}$ & $\begin{array}{c}\text { Max CR } \\
{[\times]}\end{array}$ & $\begin{array}{c}\text { Max cell } \\
\text { current }[\mathrm{A}]\end{array}$ & $\begin{array}{c}\text { Number of } \\
\text { diodes per } \\
\text { cell }\end{array}$ & $\begin{array}{l}\text { Maximum forward } \\
\text { current per diode } \\
{[\mathrm{A}]}\end{array}$ & Safety factor \\
\hline AZUR SPACE [17] & $10 \times 10$ & 1000 & 13.088 & 2 & 10 & 1.53 \\
\hline Emcore [19] & $5 \times 5$ & 1000 & 4.4 & 1 & 10 & 2.23 \\
\hline Spectrolab [18] & $10 \times 10$ & 500 & 6.95 & 1 & 12 & 1.73 \\
\hline \multirow{3}{*}{ Ergonsolair [31] } & $5.5 \times 5.5$ & 500 & 2 & 1 & 10 & 5.00 \\
\hline & $7 \times 7$ & 500 & 4.5 & 1 & 10 & 2.22 \\
\hline & $10 \times 10$ & 500 & 7 & 1 & 12 & 1.71 \\
\hline $\begin{array}{l}\text { University of } \\
\text { Exeter }\end{array}$ & $10 \times 10$ & 500 & 6.587 & 1 & 10 & 1.52 \\
\hline
\end{tabular}

Laplace operator and $k \cdot \nabla^{2} T$ expresses the heat fluxes in the three dimensions of an isotropic medium [36]. In Cartesian coordinates it is reported in the following form:

$$
\nabla^{2} T=\frac{\partial^{2} T}{\partial x^{2}}+\frac{\partial^{2} T}{\partial y^{2}}+\frac{\partial^{2} T}{\partial z^{2}} .
$$

The steady-state temperature is not dependent on time and, then, $\partial T / \partial t=0$. So (2) reduces to the Poisson equation [34]:

$$
Q_{v}^{\prime}=-k \cdot \nabla^{2} T
$$

Taking into consideration the number of cells on the plate $\left(N_{\text {cell }}\right)$ and the volume of each cell $\left(V_{\text {cell }}\right)$, the heat produced by all the cells of the receiver $(Q)$ can be expressed as

$$
Q=Q_{v}^{\prime} \cdot V_{\text {cell }} \cdot N_{\text {cell }} \text {. }
$$

Some boundary conditions are set. All the media-facing surfaces are thermally insulated (6), with the exception of the backside of the prototype. A convective heat flux is introduced on the back surface of the heat sink to model the action of the cooling system or of the natural convection. Equation (7), based on Newton's law of cooling [36], explains how this condition is modelled, taking into account the difference in temperature between the surrounding media and the surfaces of the board ( $T_{\mathrm{amb}}$ and $T_{s}$, resp.) and requiring in input the value of the heat transfer coefficient (h). This parameter describes the thermal properties of the convective exchange between a surface and the surrounding media and is influenced by different conditions such as the geometry of the surface and the properties and the motion of the fluid [37]. The solder paste and the thermal interface materials are modelled as thin thermally resistive layers. The heat fluxes across these layers are described in (8) and (9), where the $u$ and $d$ subscripts refer, respectively, to the upside and the downside of the layer. For thermally resistive layers, only the thermal conductivity $\left(k_{\text {trl }}\right)$ and the thickness $\left(t_{\text {trl }}\right)$ are required in input. Consider

$$
\begin{aligned}
& \mathbf{q}=0 \\
& \mathbf{q}=h \cdot\left(T_{s}-T_{\mathrm{amb}}\right)
\end{aligned}
$$

$$
\begin{aligned}
& \mathbf{q}_{u}=-k_{u} \cdot \nabla T_{u}=-k_{\mathrm{trl}} \cdot \frac{\left(T_{u}-T_{d}\right)}{t_{\mathrm{trl}}} \\
& \mathbf{q}_{d}=-k_{d} \cdot \nabla T_{d}=-k_{\mathrm{trl}} \cdot \frac{\left(T_{d}-T_{u}\right)}{t_{\mathrm{trl}}} .
\end{aligned}
$$

3.2. Receiver Geometry and Substrate. In the first approach, a single-cell geometry is reproduced in the software environment (Figure 3): the solar cell (CC) is placed onto the copper layer $(\mathrm{CuL})$, which is accommodated onto a $21 \mathrm{~mm} \times 21 \mathrm{~mm}$ heat sink through a dielectric layer. The interconnectors (IC) are modelled as $0.025 \mathrm{~mm}$ thick silver tabs. The diode (Ds) is not considered in these thermal investigations, due to the small current flowing through it when the system is in operation. In this investigation, the copper pattern is inspired by the design of the commercial AZUR SPACE assembly, and the densely packed design is obtained by repeating the conductive patterns on the large aluminum board.

The simulations are conducted to predict the steady-state thermal behaviour of the receiver. Three different substrates are considered: a printed circuit board (PCB), a direct bonded copper (DBC), and an insulated metal substrate (IMS). The thicknesses of the layers are established on the basis of the commercially available products or references and are reported in Table 3 .

The COMSOL's "Heat transfer" module, used in this simulation, requires three proprieties for each material: the thermal conductivity, the density, and the heat capacity at constant pressure. Wherever available, the COMSOL builtin materials are used, such as copper and aluminum. In other cases, the values are set according to external references (Table 4).

The solder pastes used in all the substrates and the marble resin, which acts as a dielectric in the considered PCBs and IMSs, are modelled as thin thermally resistive layers: for this function, COMSOL requires in input the thickness and the thermal conductivity only (Table 5).

No Joule heating is considered: as proved in [38], the raising in temperature due to the Ohmic losses is negligible. All the pictures show temperatures in Celsius degrees. The temperature distribution and the isothermal contours are 
TABLE 3: Thicknesses and materials for the modelled substrates.

\begin{tabular}{lccc}
\hline Layer & PCB & DBC & IMS \\
\hline Interconnectors & $0.025 \mathrm{~mm} \mathrm{Ag}$ & $0.025 \mathrm{~mm} \mathrm{Ag}$ & $0.025 \mathrm{~mm} \mathrm{Ag}$ \\
Cell & $0.190 \mathrm{~mm} \mathrm{Ge}$ & $0.190 \mathrm{~mm} \mathrm{Ge}$ & $0.190 \mathrm{~mm} \mathrm{Ge}$ \\
Solder paste & $0.125 \mathrm{~mm} \mathrm{solder}$ & $0.125 \mathrm{~mm} \mathrm{solder}$ & $0.125 \mathrm{~mm} \mathrm{solder}$ \\
Conductive layer & $0.035 \mathrm{~mm} \mathrm{Cu}$ & $0.30 \mathrm{~mm} \mathrm{Cu}$ & $0.035 \mathrm{~mm} \mathrm{Cu}$ \\
Dielectric & $4.5 \mu \mathrm{m}$ marble resin & $0.63 \mathrm{~mm} \mathrm{AlN}$ & $4.5 \mu \mathrm{m} \mathrm{marble} \mathrm{resin}$ \\
Heat sink & $1.6 \mathrm{~mm} \mathrm{FR}-4$ & $0.30 \mathrm{~mm} \mathrm{Cu}$ & $1.6 \mathrm{~mm} \mathrm{Al}$ \\
Reference & {$[38]$} & {$[39]$} & {$[40]$} \\
\hline
\end{tabular}

TABle 4: Proprieties of materials (materials marked with $*$ are COMSOL built-in materials).

\begin{tabular}{lccc}
\hline Materials & Thermal conductivity $[\mathrm{W} / \mathrm{Km}]$ & Density $\left[\mathrm{kg} / \mathrm{m}^{3}\right]$ & Heat Capacity $[\mathrm{J} / \mathrm{kgK}]$ \\
\hline Aluminum nitride & 285 & 3260 & 740 \\
Aluminum $^{*}$ & 160 & 2700 & 900 \\
Copper $^{*}$ & 400 & 8700 & 385 \\
FR-4 & 1.7 & 1850 & 600 \\
Germanium & 60 & 5323 & 320 \\
\hline
\end{tabular}

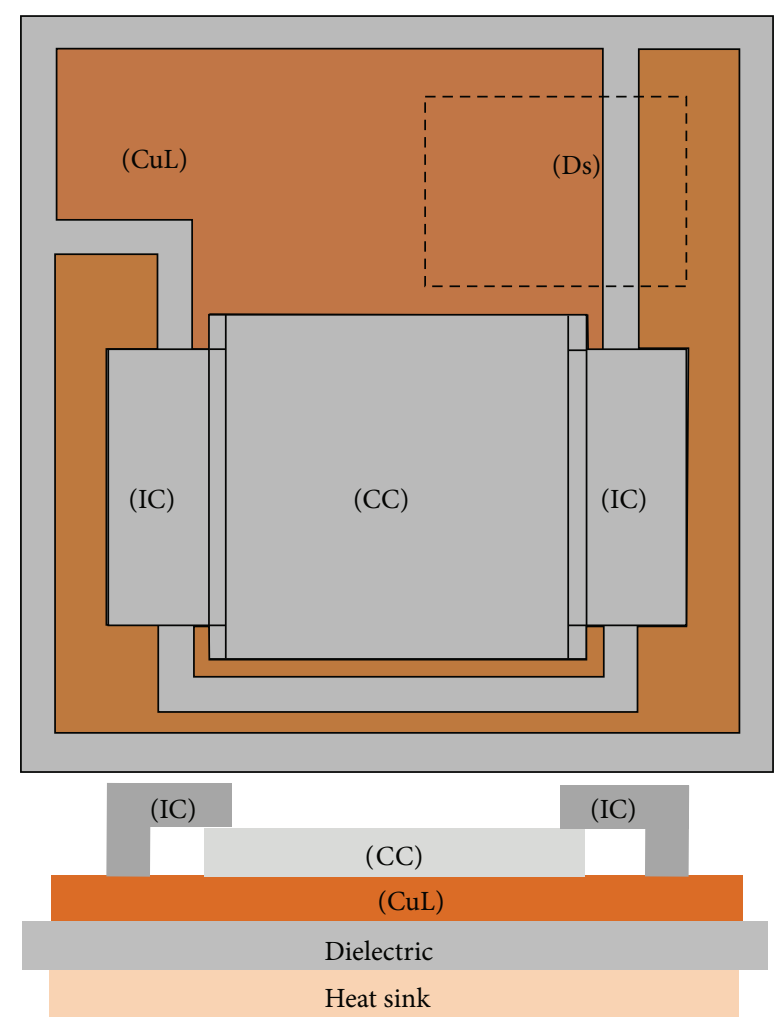

FIGURE 3: Front view and cross section of the single-cell receiver developed in COMSOL.

represented: the scale gradually ranges from red, for high temperatures, to blue, for lower temperatures. The 3D rendering of the simulations is generally shown from either one or two views: a front view of the top surface and a lateral $3 \mathrm{D}$ view.

3.3. Selection of the Substrate. According to Royne et al. [41], a well dimensioned cooling system for densely packed
TABLE 5: Conductivity and thickness of the thermally resistive layers.

\begin{tabular}{lcc}
\hline Materials & Thermal conductivity $[\mathrm{W} / \mathrm{Km}]$ & Thickness $[\mathrm{mm}]$ \\
\hline Marble resin & 3.0 & 0.0045 \\
Solder paste & 4.5 & 0.1250 \\
\hline
\end{tabular}

HCPV receiver should have a thermal resistance lower than $10^{-4} \mathrm{Km}^{2} / \mathrm{W}$. Taking into account this value, the behavior of the three substrates was reported in [38]. The investigation predicted a maximum cell temperature ranging between 30 and $32^{\circ} \mathrm{C}$ for DBC and IMS, whereas the PCB was found to achieve nonacceptable peak temperatures. The values obtained by the model are below the HCPV cell operating temperature range $[42,43]$. For this reason, in the present work, a lower thermal resistance is considered for a more realistic model.

The following simulations are conducted taking into account the Concentrator Standard Test Conditions (CSTCs) [44]: a $1000 \mathrm{~W} / \mathrm{m}^{2} \mathrm{DNI}$ and an ambient temperature of $25^{\circ} \mathrm{C}$. The cell is modelled as a heat source: considering the AZUR SPACE 3C40C cell's peak-efficiency of $37.2 \%$ at 500x and an optical efficiency of $85 \%$, an overall heat production of $26.7 \mathrm{~W} / \mathrm{cm}^{2}$ is predicted. The heat sink generally works at temperatures up to $25^{\circ} \mathrm{C}$ lower than that of the cell [45]: considering a max cell temperature of $100^{\circ} \mathrm{C}$, the heat sink should not overtake temperatures of $75^{\circ} \mathrm{C}$.

The minimum resistance per mass unit is then given as follows [41]:

$$
R^{*}=\frac{A \cdot \Delta T}{Q_{\text {cell }}},
$$

where $A$ is the area of the thermal exchanging surface, $\Delta T$ is the temperature difference between the heat sink and the ambient, and $Q_{\text {cell }}$ is the heat produced by the cell. Considering that all the heat produced by the cell would reach the heat sink, a single-cell receiver with a $21 \mathrm{~mm} \times$ 


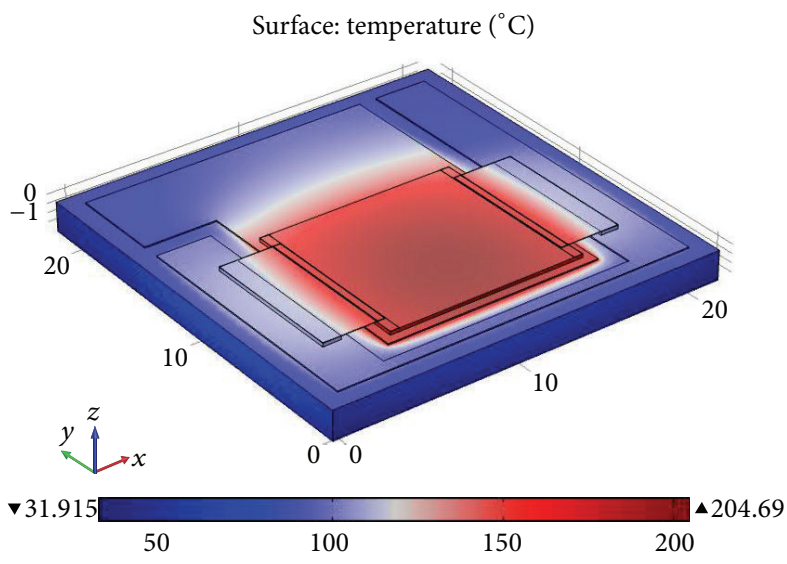

(a)
Isosurface: temperature $\left({ }^{\circ} \mathrm{C}\right)$

Arrow volume: total heat flux

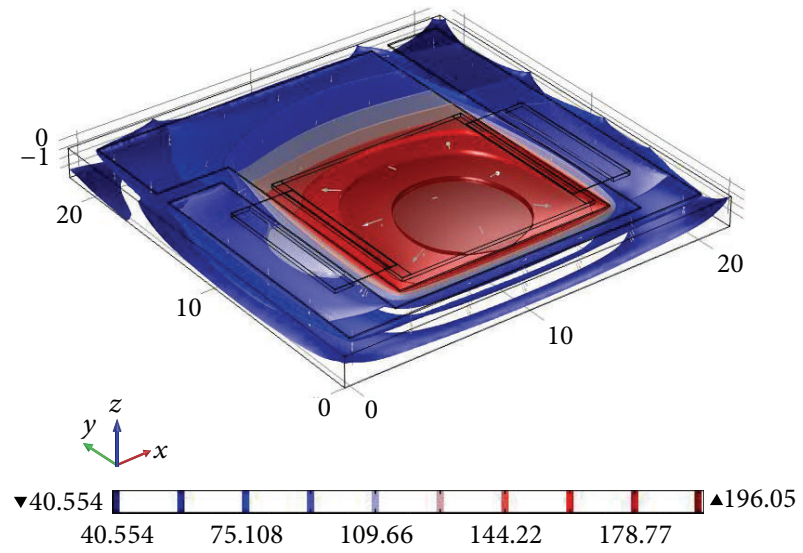

(b)

FIgURE 4: Temperature distribution (a) and isothermal contours (b) in the PCB based assembly, in ${ }^{\circ} \mathrm{C}$. Max cell's temperature: $204.7^{\circ} \mathrm{C}$.

$21 \mathrm{~mm}$ surface would require a minimum resistance of about $1250 \mathrm{Km}^{2} / \mathrm{W}$. For this reason, this value is then introduced in the model to simulate the action of the cooling system.

This second investigation confirmed that DBC and IMS behaved similarly in terms of heat removal, even in presence of a less performing cooler. The DBC achieved a maximum cell temperature of $75.6^{\circ} \mathrm{C}$ (Figure 5), whereas the IMS reached $73.8^{\circ} \mathrm{C}$ (Figure 6). In these conditions, instead, the temperature of a HCPV cell mounted on a PCB would overtake $200^{\circ} \mathrm{C}$ (Figure 4 ).

3.4. Full Scale Simulation. Similarly, a full scale simulation of the IMS-based receiver is conducted. A surface of $21 \mathrm{~mm} \times$ $21 \mathrm{~mm}$ is left around of each cell. Each secondary concentrator requires a $20 \mathrm{~mm} \times 20 \mathrm{~mm}$ entry aperture to achieve a $4 \mathrm{x}$ concentration on a $10 \mathrm{~mm} \times 10 \mathrm{~mm}$ cell. Moreover, the thickness of the optics' walls $(1 \mathrm{~mm})$ needs to be considered, leading the total area to $21 \mathrm{~mm} \times 21 \mathrm{~mm}$. In addition, a minimum of $2 \mathrm{~mm}$ tolerance is required on each side of the substrate and, on one of the sides, $8 \mathrm{~mm}$ is added to allocate the terminal tabs used for current extraction. Taking into account these values, an aluminum board sized $255.0 \mathrm{~mm} \times$ $262.5 \mathrm{~mm}$ is designed.

The simulation predicts the thermal response of the assembly and proves the ability to remove the waste heat even in a densely packed configuration. The results are shown in Figures 7 and 8: the first image reports the distribution of the temperature across the plate and the second one presents the temperature contours. The final maximum temperature is similar to that reached in the single-cell simulation: $76.5^{\circ} \mathrm{C}$. This means that the large IMS can well perform when coupled to an appropriate cooling system: the plate is able to remove the heat from the cells to let the system work at steady-state in a suitable operating temperature range.

A maximum difference of temperature of $14^{\circ} \mathrm{C}$ is registered among the cells installed in the assembly: the minimum temperature, achieved by the cells on the edge, is due to the
$1 \mathrm{~cm}$ room left on one side of the board to allocate the tabs for current extraction. Unfortunately, it is not possible to reduce that space and, on the other hand, adding the same room in the other edges will increase the temperature gradient, without any positive effect on the system's performance.

In order to predict the behaviour of the system under a wider range of conditions, the system is then tested under the worst case conditions, when all the concentrated sunlight is converted into heat. In this case, the cell's efficiency is considered to fall to $0 \%$ : the heat production then rises to $42.5 \mathrm{~W} / \mathrm{cm}^{2}$ and a maximum cell's temperature of $150^{\circ} \mathrm{C}$ can be allowed [26]. As shown in Figures 9 and 10, the insulated metal substrate is able to successfully handle the large amount of heat: the cells are expected to achieve a maximum temperature of $115^{\circ} \mathrm{C}$.

\section{The Conductive Layer}

The design of the electrical circuit is developed to allocate all the components, to have a high efficiency, and to be easy to realize. In order to enhance the performances, the same copper plate is used to directly connect the negative pad of the cell with the positive one of the following cell. This way, the number of connections is reduced, limiting the contact resistances. To facilitate the manufacturing, the whole copper pattern is designed to be made of only few shapes, periodically repeated in the space to obtain the final drawing.

The pattern is realized taking into account the requirements and the restrictions of the optical geometries and the recommendations of the standards, which are listed in the next section. In the designing stage, AutoCAD is used to check the matching between the receiver's geometry and the optics systems restrictions. A symbolic representation of the HCPV key components is shown in Figure 11: the same symbols are used in all the drawings reported in the present paper.

4.1. The IPC Standards Restrictions. The design is drawn up according to the IPC-2221 Generic Standards on Printed 


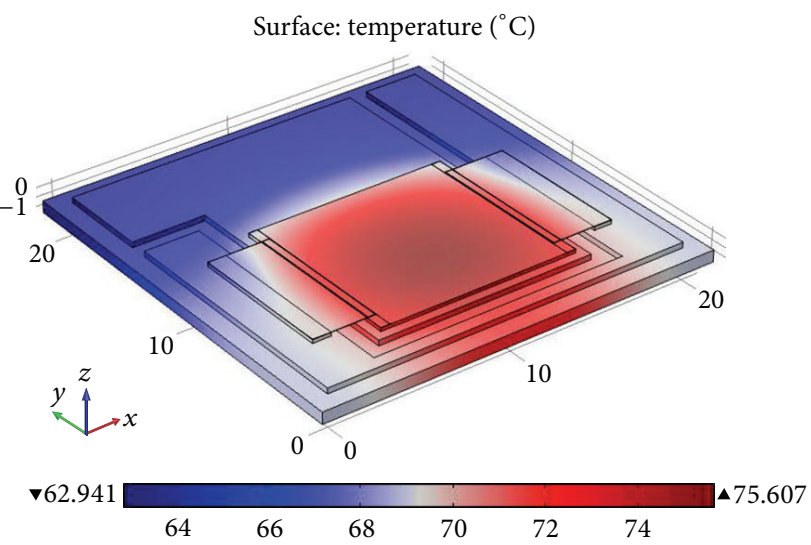

(a)

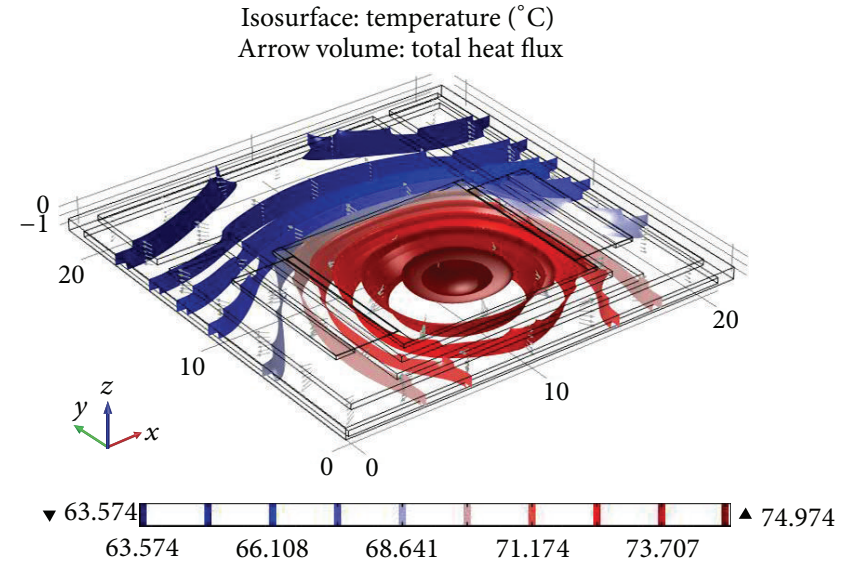

(b)

Figure 5: Temperature distribution (a) and isothermal contours (b) in the DBC based assembly, in ${ }^{\circ} \mathrm{C}$. Max cell's temperature: $75.6^{\circ} \mathrm{C}$.

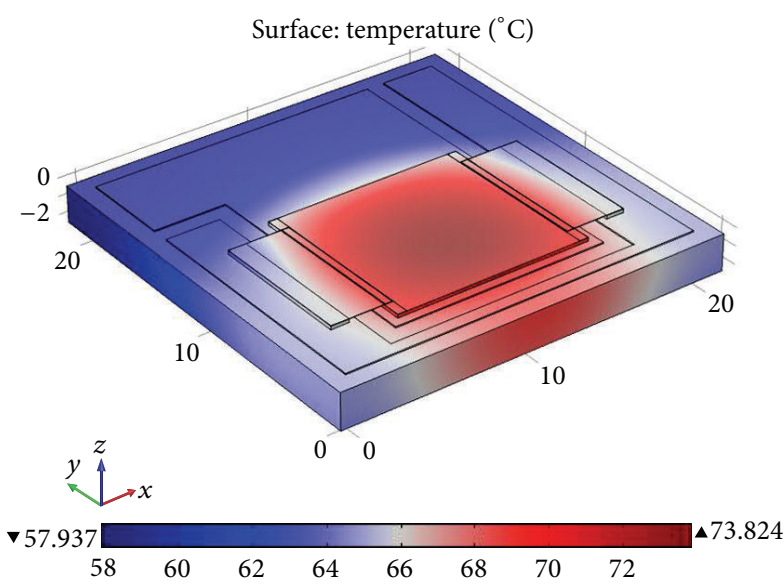

(a)

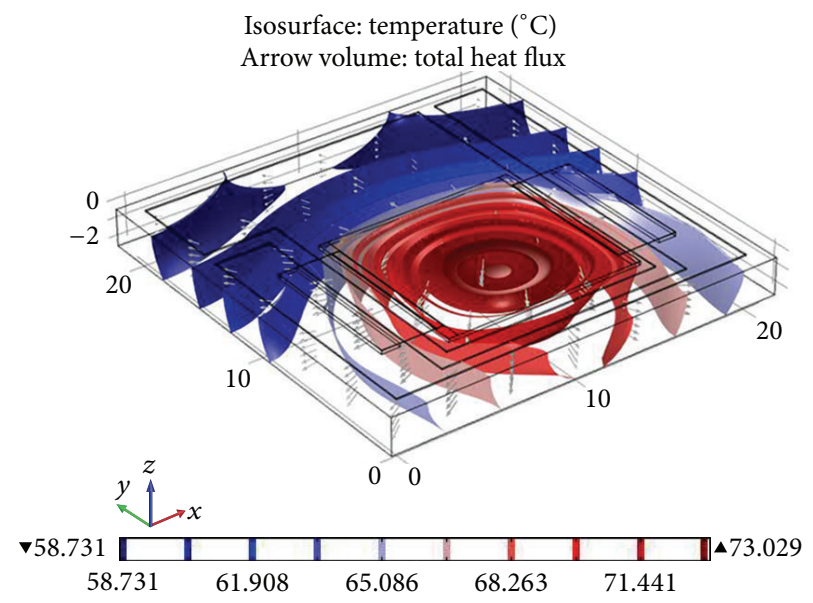

(b)

Figure 6: Temperature distribution (a) and isothermal contours (b) in the IMS based assembly, in ${ }^{\circ} \mathrm{C}$. Max cell's temperature: $73.8^{\circ} \mathrm{C}$.

Board Design [46], produced by the Association Connecting Electronics Industries. A $70 \mu \mathrm{m}$ thick copper is considered for this application; the most common $35 \mu \mathrm{m}$ thickness is not enough to safely carry the nominal currents in the restricted volumes available in $\mathrm{HCPV}$. In order to limit the increase in temperature due to the Joule losses to less than $5^{\circ} \mathrm{C}$, the minimum $70 \mu \mathrm{m}$ thick copper widths have to be equal to or larger than $1.17 \mathrm{~mm}$ (Figure 12(a)) where a maximum short-circuit current of $3.293 \mathrm{~A}$ is expected to flow and larger than $3.05 \mathrm{~mm}$ (Figure 12(b)) where the short-circuit current can rise up to $6.587 \mathrm{~A}$. Table 6 shows the minimum width required for a $70 \mu \mathrm{m}$ thick copper plate depending on the conductor's temperature and on the maximum current flowing into it. In the proposed designs, a $10 \%$ tolerance and the effects of the thermal expansion are considered as well and the minimum widths are increased accordingly.

Across the plate, adjacent copper shapes face various voltages while in operation. In conditions of open circuit at 500x, the negative pads of two consecutive cells face a difference up to $3.17 \mathrm{~V}$. The ends of two consecutive rows meet a maximum difference of $76.08 \mathrm{~V}$. The largest voltage difference is the one registered between the last pad of one series and the first one of the other one; there, the shapes face a maximum difference of $228.24 \mathrm{~V}$. The standards strike out clearly the required electrical clearance between DC external coated conductors: $0.13 \mathrm{~mm}$ for any voltages lower than $100 \mathrm{~V}$ and $0.40 \mathrm{~mm}$ for voltages up to $300 \mathrm{~V}$.

4.2. The Electrical Circuitry Pattern. The copper pattern is built to allocate two series of 72 cells each: each series is expected to produce $6.440 \mathrm{~A}$ at about $208 \mathrm{~V}$ at the maximum power point. A $4.5 \mu \mathrm{m}$ thick layer of marble resin is used to bond the aluminum substrate and the conductors. It works as a dielectric as well and has to be able to face a maximum open circuit voltage of $230 \mathrm{~V}$ per series. It is a DC dielectric strength of $60 \cdot 10^{3} \mathrm{~V} / \mathrm{mm}$, which means that it is able to support maximum voltages of $270 \mathrm{~V}$. 


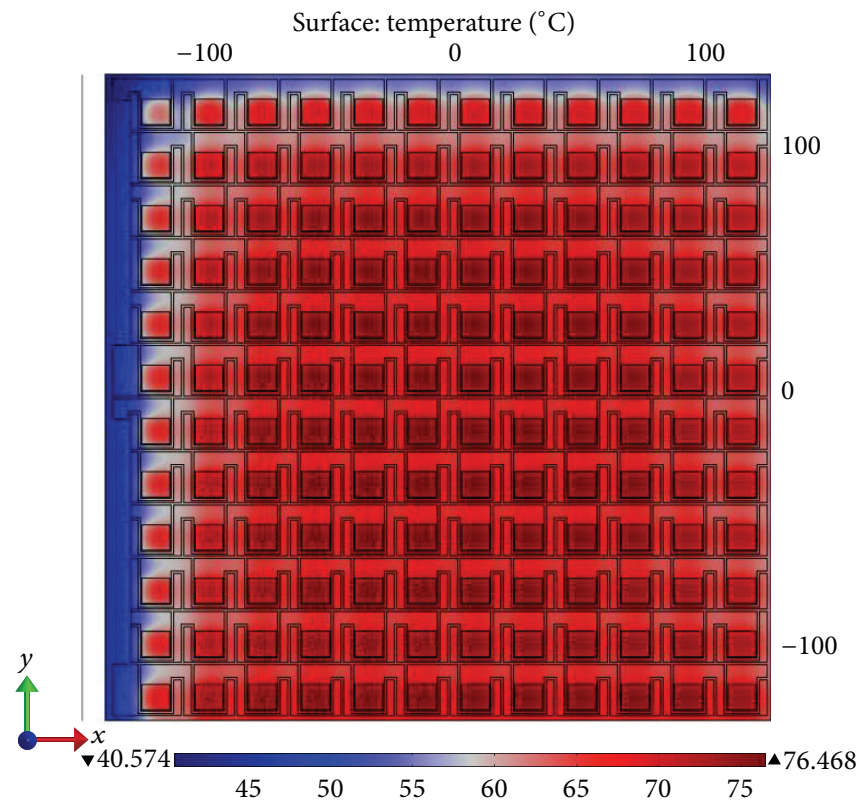

(a)

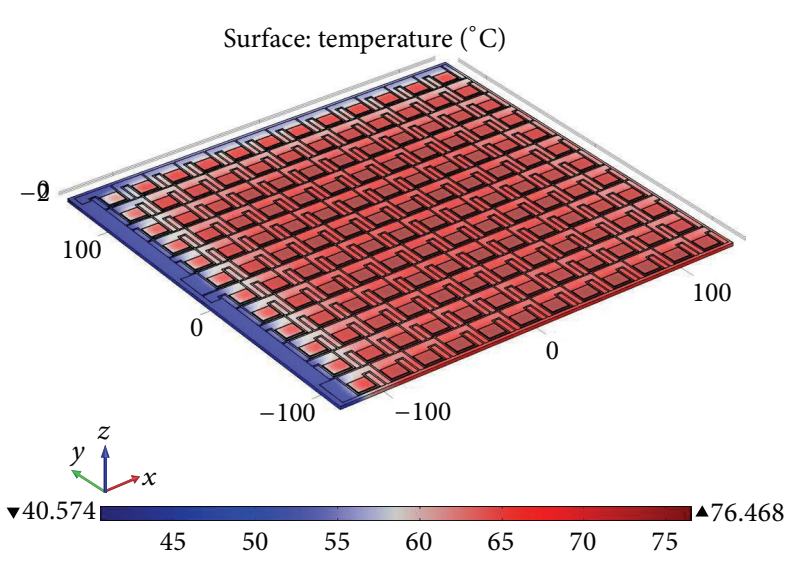

(b)

Figure 7: Front view (a) and lateral view (b) of the temperature distribution of the full scaled board in ${ }^{\circ} \mathrm{C}$. Max. cell's temperature: $76.5^{\circ} \mathrm{C}$. Min. cell's temperature: $62.5^{\circ} \mathrm{C}$.

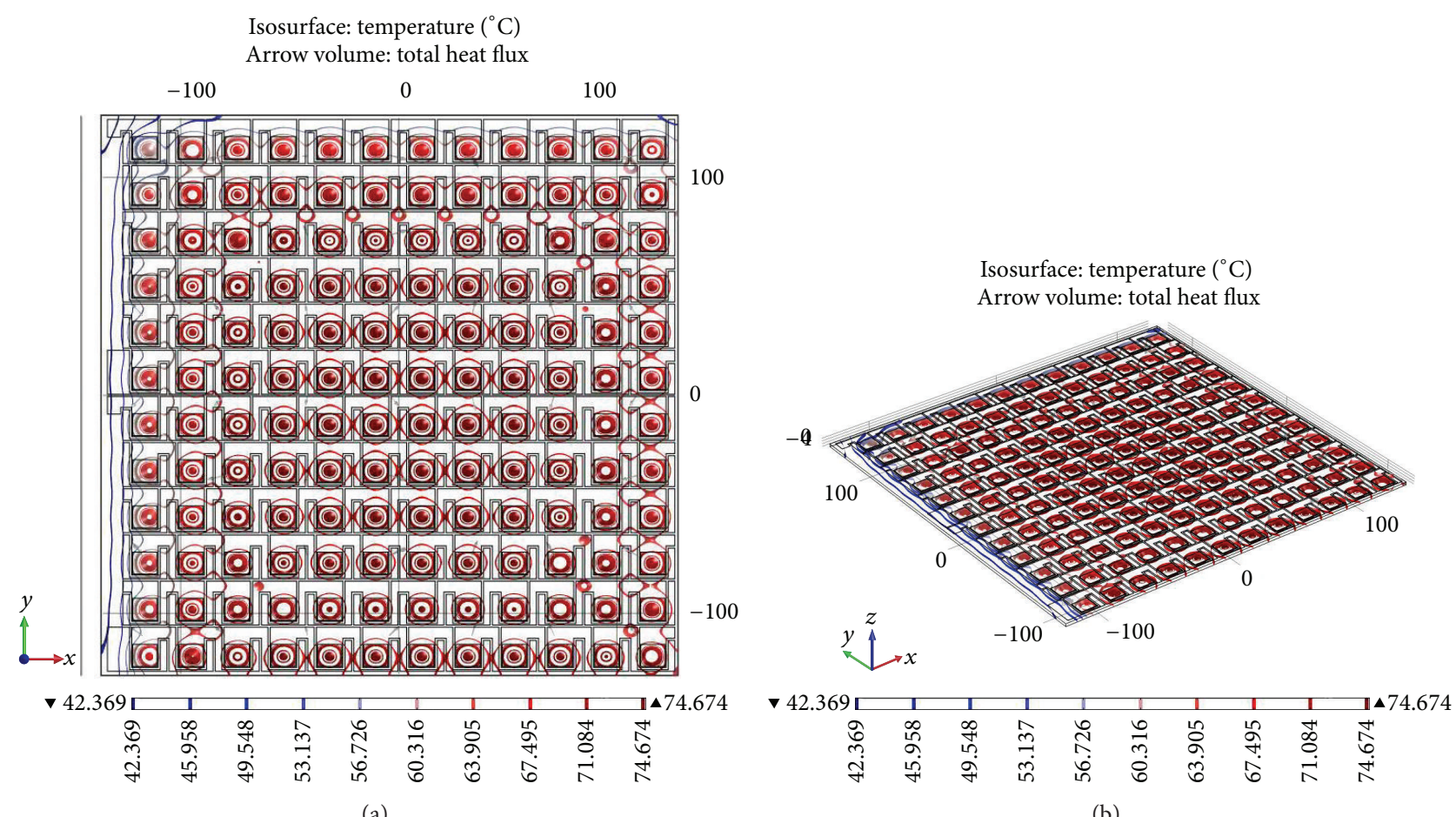

(a)

(b)

Figure 8: Front view (a) and lateral view (b) of the isothermal contours in the assembly of the full scaled board in ${ }^{\circ} \mathrm{C}$.

TABLE 6: Minimum width (in $\mathrm{mm}$ ) of the $70 \mu \mathrm{m}$ thick copper, for ambient temperature of $25^{\circ} \mathrm{C}$, depending on current and copper's temperature (according to the IPC-2221 Standards).

\begin{tabular}{lccccccccc}
\hline Current versus temperature increase & $3^{\circ} \mathrm{C}$ & $4^{\circ} \mathrm{C}$ & $5^{\circ} \mathrm{C}$ & $15^{\circ} \mathrm{C}$ & $25^{\circ} \mathrm{C}$ & $35^{\circ} \mathrm{C}$ & $45^{\circ} \mathrm{C}$ & $55^{\circ} \mathrm{C}$ & $65^{\circ} \mathrm{C}$ \\
\hline $6.5870 \mathrm{~A}$ & 4.26 & 3.58 & 3.12 & 1.60 & 1.18 & 0.96 & 0.82 & 0.73 & 0.66 \\
$3.2935 \mathrm{~A}$ & 1.64 & 1.37 & 1.20 & 0.62 & 0.45 & 0.37 & 0.32 & 0.28 & 0.25 \\
\hline
\end{tabular}




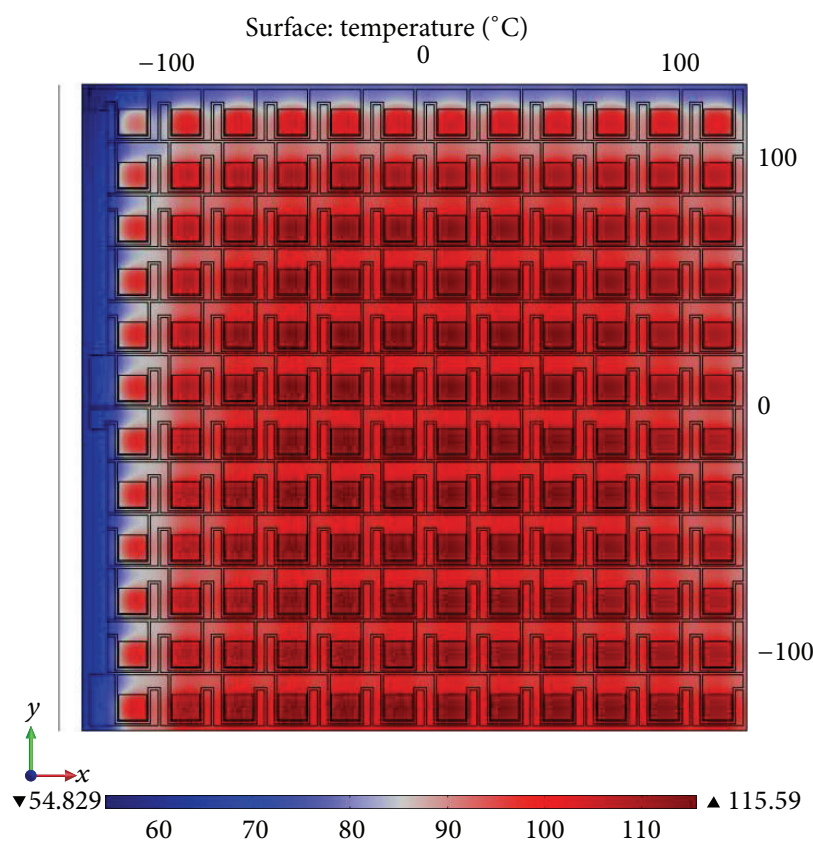

(a)

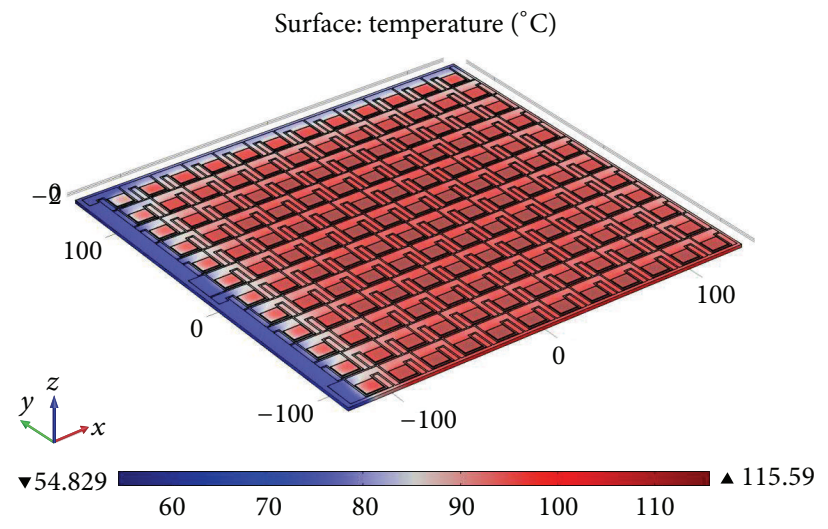

(b)

Figure 9: Front view (a) and lateral view (b) of the temperature distribution of the full scaled board in the worst case conditions in ${ }^{\circ} \mathrm{C}$. Max. cell's temperature: $115.6^{\circ} \mathrm{C}$. Min. cell's temperature: $91.9^{\circ} \mathrm{C}$.

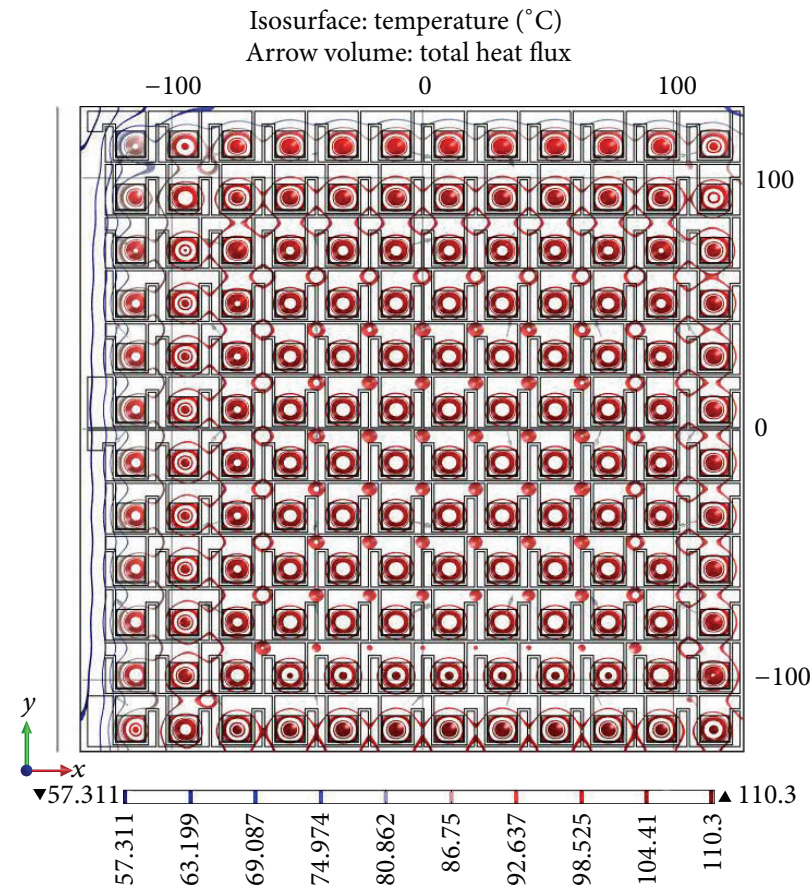

(a)

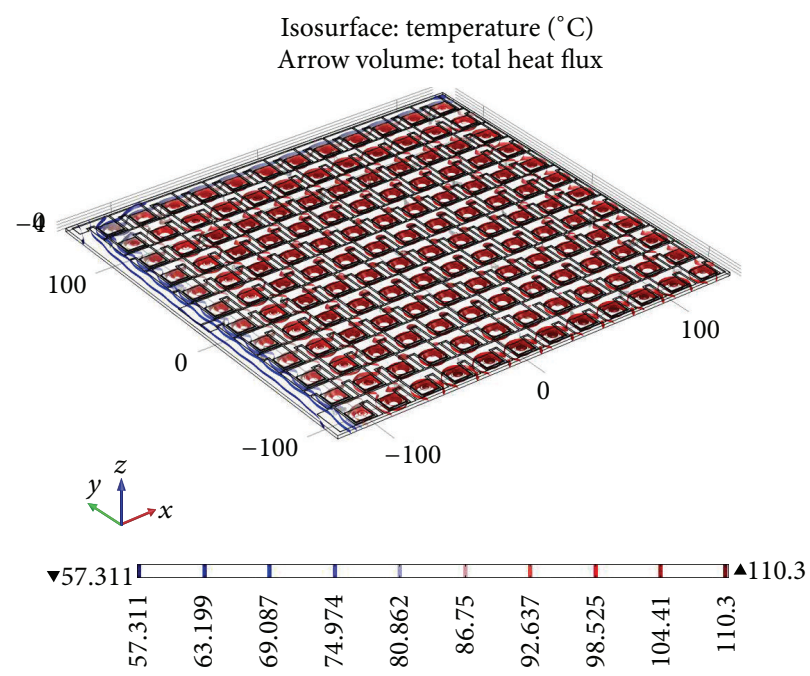

(b)

Figure 10: Front view (a) and lateral view (b) of the isothermal contours of the full scaled board in the worst case conditions in ${ }^{\circ} \mathrm{C}$. 


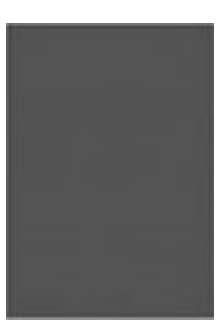

(a)

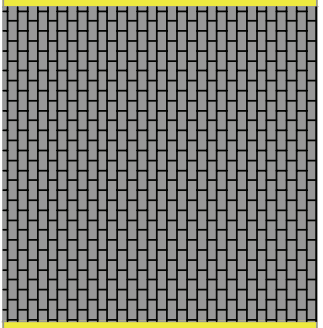

(b)

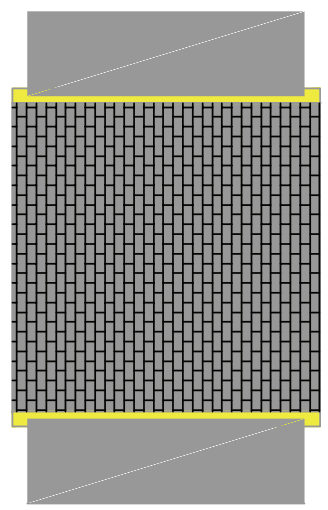

(c)

Figure 11: Key of the components schematics: (a) diode, (b) bare cell, and (c) cell with front interconnectors.

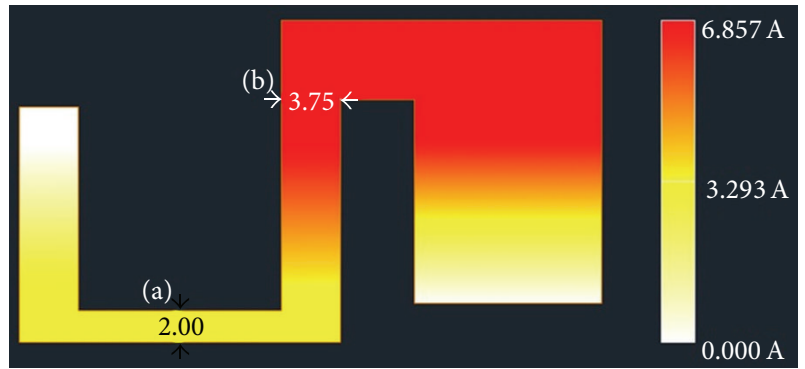

FIGURE 12: Current distribution across the C2 copper shape. The dimensions are in $\mathrm{mm}$.

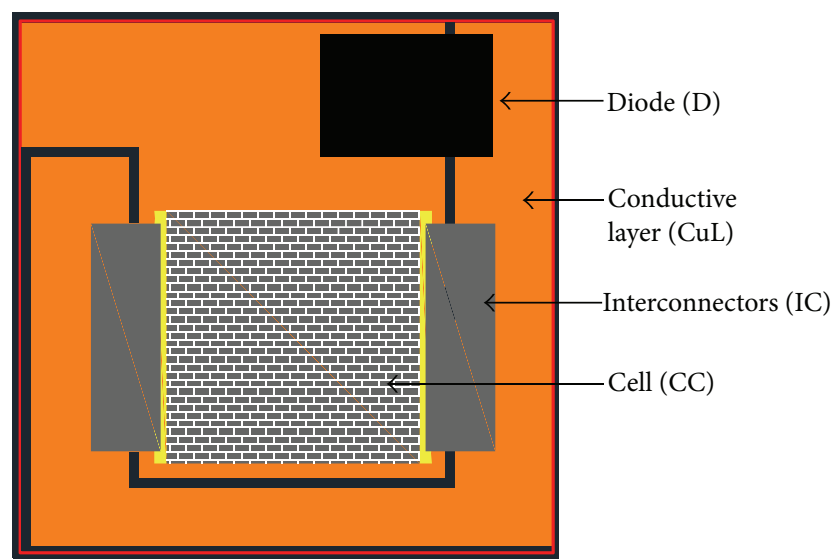

Figure 13: Components distribution across the $21 \mathrm{~mm} \times 21 \mathrm{~mm}$ surface, delimited by the red square.

In the designing stage AutoCAD is used in order to check the matching between the receiver's geometry and the optics systems restrictions. The main challenge is to fit all the components in the available space. A $4 \mathrm{x}$ secondary system is placed above the plate: this means that the surface available to allocate the cell, the diode, the interconnectors, and the conductive layers, inclusive of the clearances, is four times larger than the cell's active area $(10 \mathrm{~mm} \times 10 \mathrm{~mm})$. The edges of the optics structure have a thickness of a $1 \mathrm{~mm}$; the available surface rises then up to $21 \mathrm{~mm} \times 21 \mathrm{~mm}$ and it is marked by the red square in Figure 13.

The geometry, shown in Figure 14, is specifically developed to fit the original 500x optical system, but it can be easily adapted to fit different set of optics. The design is based on four simple shapes (Figure 15), named C1, C2, C3, and C4 [47]. The full scale plate is obtained through the appropriate repetition of these shapes on the conductive layer.

The large, 144-cell conductive layer is composed of 146 copper elements, opportunely etched on the substrate, as shown in Figure 16. C2 is repeated 132 times. C3 recurs 10 times: it is used at the end of each row, excepted for the start and the end of each series, where $\mathrm{C} 1$ and $\mathrm{C} 4$ are, respectively, placed. C1 and C4 are then present twice each on the 144cell plate, respectively, at the positive and the negative ends of each series. The two series are named A and B.

4.3. Features of the New Design. In any electronic application, interconnectors represent one of the weakest points, because of the high electrical contact resistance and the fragility of the bonding. The original design of the copper pattern designed in this work has only one set of interconnections between adjacent cells: one shape of copper is used both as landing surface for the interconnectors coming from the negative pole of the cell and as mounting pad for the positive pole of the adjacent cell. This approach allows lowering the electrical resistance of the circuit and, thus, the electrical losses.

A second feature of the design is the scalability: it can be easily adapted to allocate a different number of cells. Opportunely combining the copper shapes, it is possible to create less or more populated arrays of aligned cells. In the present work, the design has been used to produce several single-cell receivers, a 16-cell receiver [38], and the presented 144-cell receiver.

4.4. Thermal Expansion Analysis. An investigation about the effects of the thermal expansion is sorted out, in order to prevent problems due to the high temperatures involved. The plate is designed and manufactured at a room temperature of $25^{\circ} \mathrm{C}$. In case failures, the system can face temperature up to $150^{\circ} \mathrm{C}$. The maximum thermal expansion is then 


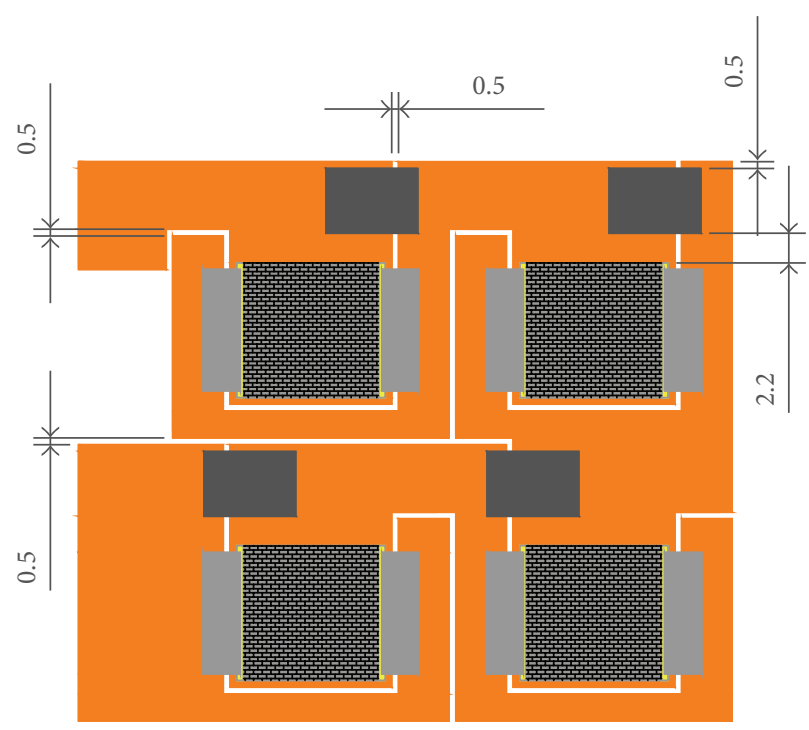

(a)

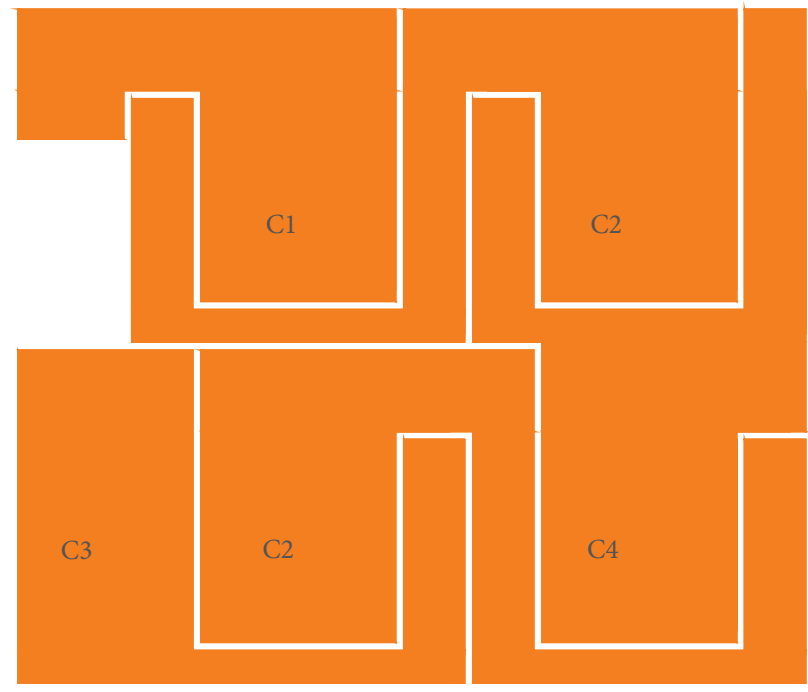

(b)

Figure 14: A four-cell V3.1 pattern. In (a), cells and diodes are reported with dimensions in mm. In (b) the copper shapes employed for the pattern are highlighted.

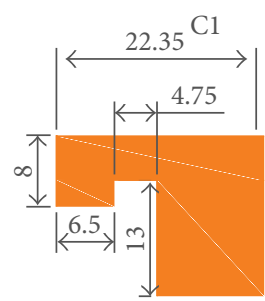

$\times 2$

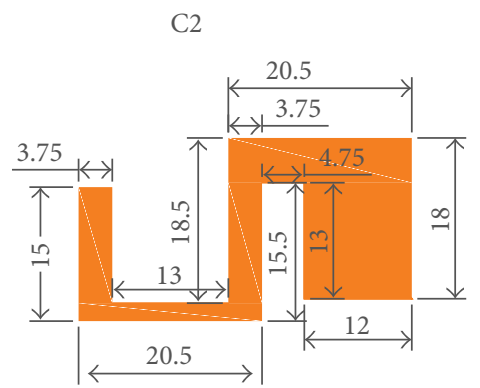

$\times 132$

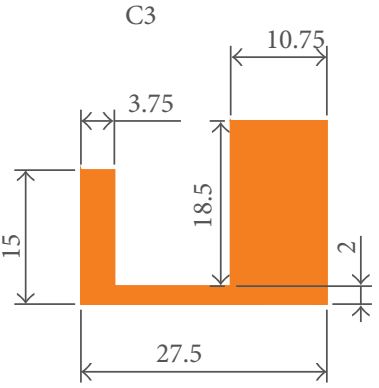

$\times 2$
$\mathrm{C} 4$

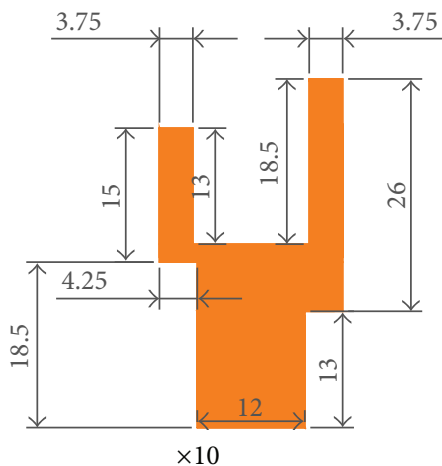

FIgURE 15: The four shapes of the V3.0: C1 recurs twice, C2 recurs 132 times, C3 recurs twice, and C4 recurs 10 times in the 144 -cell design. Dimensions are in $\mathrm{mm}$.

calculated between these two extreme temperatures: a maximum difference of temperature $\left(\Delta T_{c u}\right)$ of $125^{\circ} \mathrm{C}$ is considered.

Copper has a coefficient of thermal expansion $\left(\alpha_{L}\right)$ of $17 \mathrm{ppm} /{ }^{\circ} \mathrm{C}$ and the maximum dimension $(L)$ in the presented design is $20.5 \mathrm{~mm}$. According to the standard equation for the linear thermal expansion (11), the maximum expected deformation $(\Delta L)$ due to the temperature is $0.00435 \mathrm{~mm}$. The linear thermal expansion equation is expressed as

$$
\frac{\Delta L}{L}=\alpha_{L} \cdot \Delta T_{c u} .
$$

Considering the expansion of both the copper shapes facing a gap, a decrease in distance of about $0.01 \mathrm{~mm}$ will still maintain the gap above the minimum value recommended by the standards $(0.4 \mathrm{~mm})$.

\subsection{Top Interconnections}

4.5.1. Wire Bonding Technology. Wire bonding is used to interconnect the front of the cell with the conductive layer. It is a standard process in electronics and is considered to be extremely reliable after the introduction of automatic wire bonding, low temperature bonding processes, and effective pad cleaning methods [48]. Either gold or aluminium wires are generally used. Copper wires have been developed and are gaining much attention but are not yet capillary available. In our application, $32 \mu \mathrm{m}$ thick aluminium wires were bonded, because of the higher mechanical strength of aluminium, the lower temperature required for the bonding process, and the lower cost compared to gold.

4.5.2. System Sizing. The approach suggested by Shah [49] is considered to dimension the wire bonding interconnections 


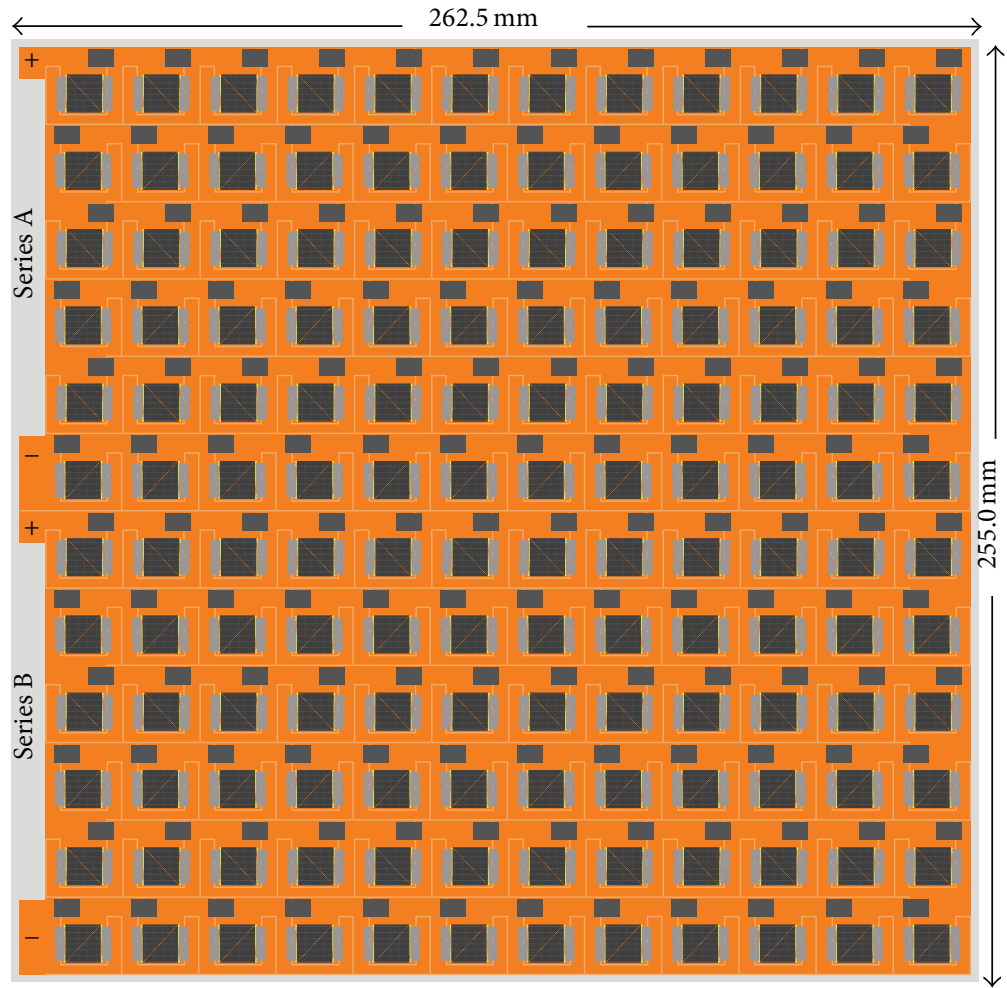

FIGURE 16: Complete assembly: the dimensions of the aluminum board are shown.

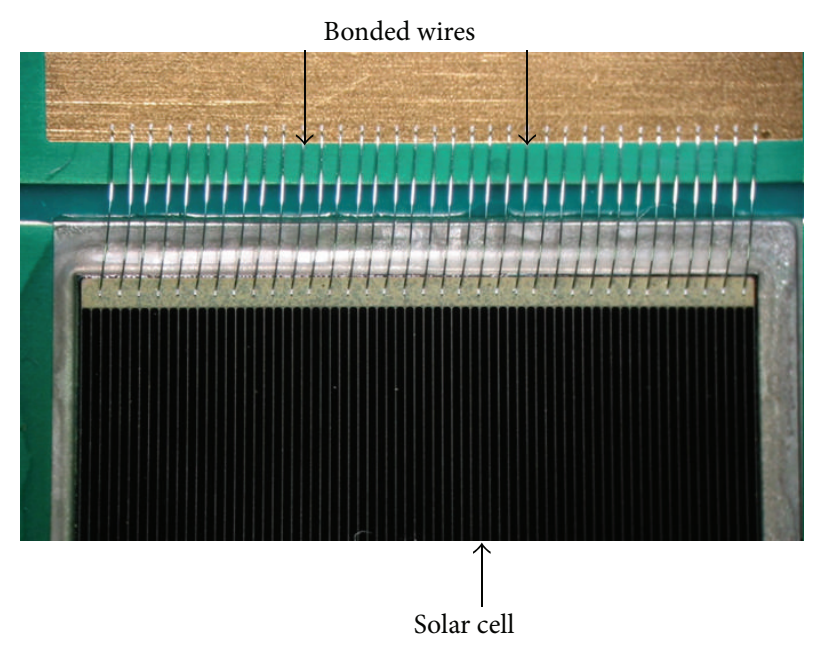

(a)

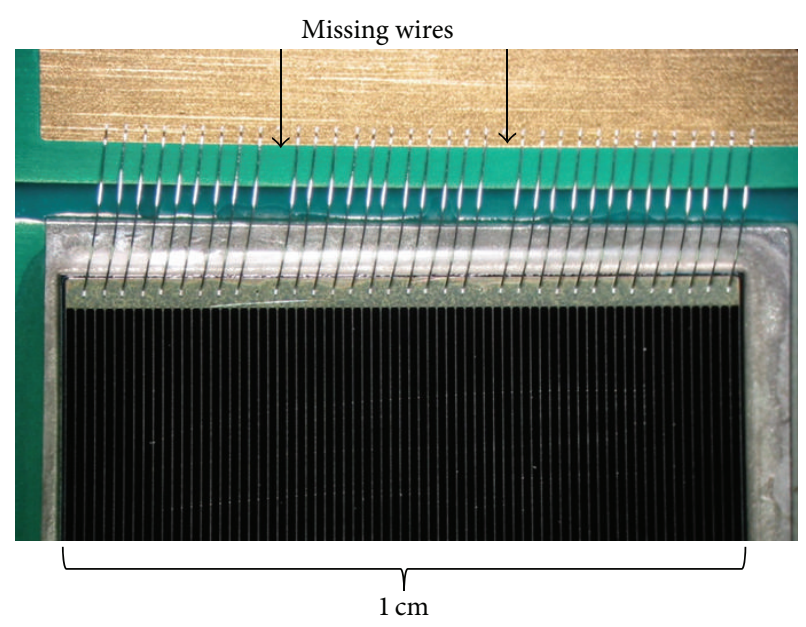

(b)

FIGURE 17: A completely bonded cell's tab (a) and a cell's tab with two missing wires (b).

of the receiver. Shah based his method on the principle that at steady-state all the heat produced by the Joule losses $\left(Q_{g}\right)$ on the wires need to be removed (12). This procedure is centered on the conservative assumption that the heat is dissipated only through thermal conductivity: the amount of heat removed through the wire $\left(Q_{r}\right)$ has to equalize $Q_{g}$. In the present case, the amount of heat generated on the wire (13) is directly proportional to the square of the current flowing through the wire itself $\left(I_{w}\right)$, with the proportion given by the electrical resistance of aluminum $\left(R_{\mathrm{Al}}\right)$. Consider

$$
\begin{aligned}
& Q_{g}=Q_{r} \\
& Q_{g}=I_{w}^{2} \cdot R_{\mathrm{Al}} .
\end{aligned}
$$


The amount of heat removed by the wire can be estimated through the equation of the heat transfer by conduction, given as

$$
\mathrm{Q}_{r}=\frac{k_{\mathrm{Al}} \cdot A_{w} \cdot \Delta T_{w}}{l_{w}},
$$

where $k_{\mathrm{Al}}$ represents the thermal conductivity of aluminum, $A_{w}$ and $l_{w}$ are, respectively, the sectional area and the length of the wire, and $\Delta T_{w}$ indicates the difference of temperature between the two ends of the wire.

The electrical resistance depends on the electrical resistivity of the material $\left(\rho_{\mathrm{Al}}\right)$ and the length and the cross-sectional area of the conductor. Applying the definition of electrical resistance (15), and considering the circular section of the wire, Shah [49] obtained (16); it can be used to determine the maximum $\left(I_{w}\right)$ current allowed to flow through one $D$-sized wire. Consider

$$
\begin{aligned}
R_{\mathrm{Al}} & =\frac{\rho_{\mathrm{Al}} \cdot l_{w}}{A_{w}} \\
I_{w} & =\frac{\pi}{4} \cdot \frac{D_{w}^{2}}{l_{w}} \cdot \sqrt{\frac{k_{\mathrm{Al}} \cdot \Delta T_{w}}{\rho_{\mathrm{Al}}}} .
\end{aligned}
$$

The current generated by the cell $\left(I_{c}\right)$ can be distributed on different wires. The minimum number of wires needed to carry it safely $\left(N_{w}\right)$ can be established through the ratio between the total amount of current and the maximum current per wire:

$$
N_{w} \geq \frac{I_{c}}{I_{w}} .
$$

Aluminum has a thermal conductivity of $205 \mathrm{~W} / \mathrm{mK}$ and an electrical resistivity of $2.82 * 10^{-8} \Omega \mathrm{m}$. Standard aluminium wires are used in this application; their diameter is $32 \mu \mathrm{m}$. The distance between the front contacts on the cell and the landing pads on the copper is $2 \mathrm{~mm}$ and corresponds to the length of the wire. Considering a difference of temperature of about $15^{\circ} \mathrm{C}$ between the two terminals of a wire, a number of 50 wires are needed to carry 6.587 A.

4.5.3. Safety Factor. In the fabrication of the cell receiver, 70 wires per cell are bonded, applying then a safety factor of about 1.4. This factor can be judged as low, but it is safe enough if the already conservative approach used for sizing is considered. Anyway, the surplus of wires is installed to overtake two issues that can occur during manufacturing and in operation: wire bond nonsticks and nonuniform current generation. Some contamination on the dies from the soldering process causes some wire bond nonsticks, like those shown in Figure 17. In the present system, the 3.75\% of the connections are found to be faulty: this means that almost 3 wires per cell are missing, out of 70 . A peak of 14 missing wires per cell is counted, with a maximum of 10 wrong connections per cell's side. The surplus of bonded wires prevents the system from dangerous overcurrents. Furthermore, the excess of wires allows the system to face any potential nonuniformity in current generation due to nonhomogeneous light distribution onto the cell's surface. Under a nonuniform illumination the cell operates locally at higher irradiance and, thus, generates higher currents $[50,51]$. A larger number of interconnections will help to distribute any surplus of current, in order not to overload some of the wires in case of nonuniform illumination.

4.6. Ohmic Losses. The plate is designed to work at a peak power of $2.678 \mathrm{~kW}_{\mathrm{p}}$ : this is the expected output from 144 cells working at the maximum power point under $500 \mathrm{x}$ at $25^{\circ} \mathrm{C}$. An analytical investigation is sorted out to determine the Ohmic losses: some electrical energy is wasted in the copper circuit and some is lost in the interconnectors. These two cases are separately studied, in order to understand the effect of the interconnections on the performances of the system. The 144cell copper pattern is made of 146 copper components, with a common thickness of $70 \mu \mathrm{m}$. The power losses are calculated for each copper shape, as reported in Table 7, taking into account the current flowing in the different portions of each shape. Considering an electrical resistivity of $1.62 \cdot 10^{-8} \Omega \mathrm{m}$ for copper, a loss of $10.50 \mathrm{~W}_{\mathrm{e}}$ is estimated while in operation. This value represents about $0.4 \%$ of the whole power output.

70 aluminum wires are installed on each cell, to transfer a current of $6.440 \mathrm{~A}$ at the maximum power point. Taking into account an electrical resistivity of $2.82 * 10^{-8} \Omega \mathrm{m}$, about $0.063 \mathrm{~W}_{\mathrm{e}}$ are going to be wasted on each cell and, then, about $9.00 \mathrm{~W}_{\mathrm{e}}$ are lost on each plate ( $0.34 \%$ of the power output). In the presented plate, an average number of 3 wires are missing on each cell; this raises the power losses to about $9.40 \mathrm{~W}_{\mathrm{e}}$, with an increase of $4.5 \%$ compared to the ideal case. It is interesting to highlight that the interconnectors are causes of almost half of the Joule losses on the plate. The wires are designed to operate safely when up to 20 of them fail on each cell. If only 50 wires are working on each cell, the power loss rises to $12.60 \mathrm{~W}_{\mathrm{e}}$ (+40\% compared to the 70 -wire case). The losses might be decreased by using materials with higher electrical conductivity: 70 gold wires per cell and 70 copper wires per cell would drop the losses per plate, respectively, to $7.80 \mathrm{~W}_{\mathrm{e}}(-12 \%)$ and $2.68 \mathrm{~W}_{\mathrm{e}}(-70 \%)$. Out of a designed peak power of $2.678 \mathrm{~kW}_{\mathrm{p}}$, a net power output of $2.658 \mathrm{~kW}_{\mathrm{p}}$ is expected to be obtained by the plate.

\section{Fabrication and Analysis of the 144-Cell HCPV Assembly}

The $262.5 \mathrm{~mm} \times 255.0 \mathrm{~mm}$ IMS plate is developed to accommodate 144 cells and to fit the $4 \mathrm{x}$ secondary concentrators as described earlier (Figure 18). The IMS has a $2.003 \mathrm{~mm}$ thick 5052 aluminum baseplate and a $70 \mu \mathrm{m}$ thick copper layer, bonded together with a $4.5 \mu \mathrm{m}$ thick marble resin. Aluminum is chosen due to its good thermal performances and its lower price than copper [52]. The whole board is produced and populated through standard electronic processes.

5.1. Indoor Characterization. The plate is tested in a WACOM WXS-300S-50 solar simulator, in order to verify the lack of faulty connections or of short-circuits that can happen in the manufacturing operation and to check the components. 
TABLE 7: Power losses breakdown in the conductive pattern.

\begin{tabular}{|c|c|c|c|c|}
\hline $\begin{array}{l}\text { Component } \\
\text { code }\end{array}$ & Geometry & $\begin{array}{c}\text { Power losses per } \\
\text { piece }[\mathrm{W}]\end{array}$ & $\begin{array}{l}\text { Number of } \\
\text { repetition in } \\
\text { 144-cell design }\end{array}$ & $\begin{array}{c}\text { Total power losses } \\
{[\mathrm{W}]}\end{array}$ \\
\hline $\mathrm{C} 1$ & & 0.013 & 2 & 0.026 \\
\hline $\mathrm{C} 2$ & & 0.077 & 132 & 10.202 \\
\hline $\mathrm{C} 3$ & & 0.014 & 10 & 0.140 \\
\hline $\mathrm{C} 4$ & & 0.067 & 2 & 0.134 \\
\hline
\end{tabular}

This device is a class AAA simulator, equipped with one xenon short arc lamp. The simulator is able to provide a continuous irradiance of $1000 \mathrm{~W} / \mathrm{m}^{2}$ at AM1.5, distributed over an area of $30 \mathrm{~cm} \times 30 \mathrm{~cm}$. Due to the dimensions of the plate, only a $1 \mathrm{x}$ indoor characterization is possible. The plate is tested at DNI $1000 \mathrm{~W} / \mathrm{m}^{2}, \mathrm{AM} 1.5$, and $28^{\circ} \mathrm{C}$. For comparison purposes, a 3C40A assembly produced by AZUR SPACE [17] is also tested in the same conditions. The $3 \mathrm{C} 40 \mathrm{~A}$ is a singlecell assembly equipped with a 3C40C cell, the same used in the plates presented in this paper. It is based on a DBC substrate and equipped with two diodes. The measured $I-V$ curves are shown in Figure 19; the two series of the boards are separately characterized and therefore named A and B (Figure 16), because the $I-V$ tracer cannot work with voltages higher than $300 \mathrm{~V}$. In this study, it is not possible to vary the irradiance, because of the impossibility for the $I-V$ tracer to measure at the same time currents lower than $10 \mathrm{~mA}$ and voltages higher than $30 \mathrm{~V}$ [53].

A short-circuit current of $11.6 \mathrm{~mA}$ is measured and open circuit voltages of $181 \mathrm{~V}$ and $180 \mathrm{~V}$ are recorded for the two cell's series on the assembly. The discrepancy in the voltage outputs might be due to the hand-placement of the components and to the solder paste contamination found during the wire bonding. The fill factor ranges between $80.3 \%$ and $80.9 \%$. The high values of fill factor prove a low series resistance in the board, whereas the shape of the $I V$ curve means that the fabrication has been properly realized: the lack of steps in the curve is due to the good connections and to the absence of mismatches between the cells.

The measured outputs, shown in Table 8 , are compared with those of the AZUR SPACE's 3C40A single-cell assembly tested in the same conditions. The average outputs of each cell of the large cell assembly are calculated; the $I V$ curves are compared in Figure 20.

For a better prediction, the measured values are refined to simulate a full scale characterization. In the following numerical investigation, the values of the series $\mathrm{A}$ are considered: an average open circuit voltage of $2.50 \mathrm{~V}$ per cell is generated. The equations reported in [54] are used to estimate the performance of the cell assembly at the designed $500 \mathrm{x}$ concentrations. The intensity of the current $(I)$ at any concentration $(X)$ can be estimated as

$$
I(X)=X \cdot I(X=1) .
$$


TABLE 8: Electrical outputs per cell of the two series of the produced cell assembly, compared with those of the commercial 3C40A assembly, under $\mathrm{AM} 1.5,1000 \mathrm{~W} / \mathrm{m}^{2}$, at $28^{\circ} \mathrm{C}$.

\begin{tabular}{lcccccr}
\hline Assembly & Number of cells & $I_{\text {sc }}[\mathrm{mA}]$ & $V_{\text {oc }}$ per cell [V] & $\begin{array}{c}P_{\text {MPp }} \text { per cell } \\
{[\mathrm{mW}]}\end{array}$ & $I_{\text {MPP }}[\mathrm{mA}]$ & $V_{\text {MPP }}$ per cell [V] \\
\hline Series A & 72 & 11.57 & 2.50 & 23.58 & 10.31 & 2.29 \\
Series B & 72 & 11.59 & 2.51 & 23.38 & 10.32 & 0.814 \\
3C40A & 1 & 12.11 & 2.58 & 25.64 & 11.00 & 2.26 \\
\hline
\end{tabular}

TABLE 9: Refined electrical outputs of the two series of the produced cell assembly, compared with those of the commercial 3C40A assembly for a concentration of 500x under AM1.5, $1000 \mathrm{~W} / \mathrm{m}^{2}$, at $25^{\circ} \mathrm{C}$.

\begin{tabular}{lcc}
\hline & $I_{\text {sc }}(500 \mathrm{x})[\mathrm{A}]$ & $V_{\text {oc-cell }}(500 \mathrm{x})[\mathrm{V}]$ \\
\hline Series A & 5.77 & 3.08 \\
Series B & 5.78 & 3.09 \\
$3 \mathrm{C} 40 \mathrm{~A}$ & 6.04 & 3.16 \\
\hline
\end{tabular}

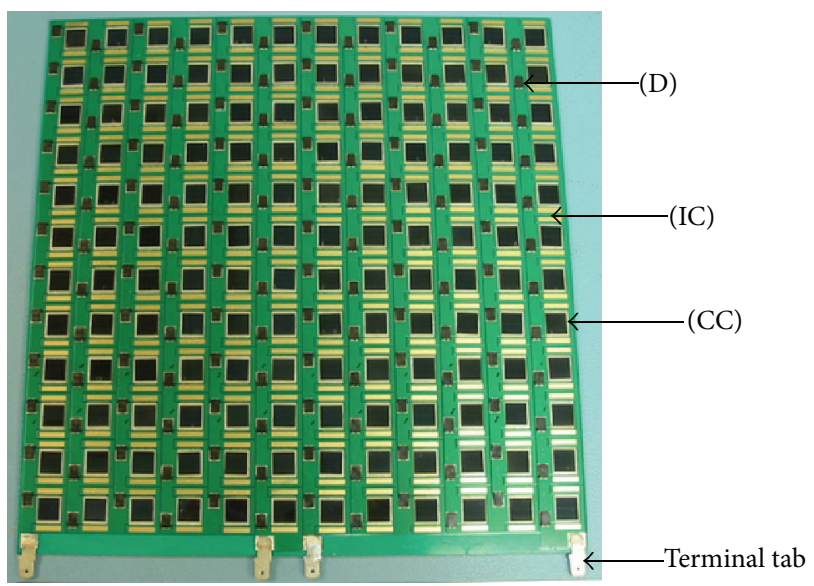

FIGURE 18: The cell assembly populated with cells (CC), interconnectors (IC), diodes (D), and terminal tabs.

The voltage $(V)$ can instead be obtained according to

$$
V(X)=V(X=1)+\frac{n \cdot k_{B} \cdot T}{q_{\mathrm{el}}} \ln (X)-I(X) \cdot R_{s},
$$

where $n$ is the ideality factor, $k_{B}$ is the Boltzmann's constant $\left(1.38 \cdot 10^{-23} \mathrm{~J} / \mathrm{K}\right), T$ is the cell's temperature, $q_{\mathrm{el}}$ is the elementary charge $\left(1.60 \cdot 10^{-19} \mathrm{C}\right)$, and $R_{s}$ is the series resistance of the circuit. An average ideality factor of 3.5 is considered [54]. The measurements are conducted at a temperature of $28^{\circ} \mathrm{C}, 3$ degrees more than the standard one. For this reason, the values obtained by (18) and (19) have to be corrected according to the temperature coefficients reported in the cell's datasheet [26]. $R_{s}$ is calculated as described in Section 4.6.

A minimum short-circuit current of $5.77 \mathrm{~A}$ and an average open circuit voltage per cell of $3.08 \mathrm{~V}$ are predicted at 500x, under CSTCs (Table 9). The current and the voltage measured for the large receiver are, respectively, $4.80 \%$ and $2.06 \%$ lower than those obtained for the commercial singlecell assembly under the same conditions [55]. This discrepancy can be justified by the difference in the cell's number

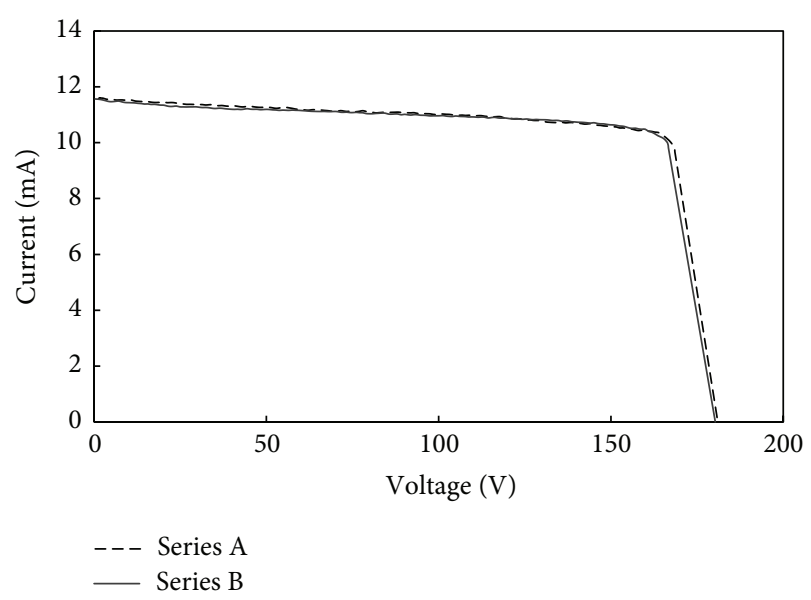

Figure 19: $I-V$ curves of the series of the fabricated assembly at $1 \mathrm{x}$ under $1000 \mathrm{~W} / \mathrm{m}^{2} \mathrm{DNI}, \mathrm{AM} 1.5$, and $28^{\circ} \mathrm{C}$ temperature.

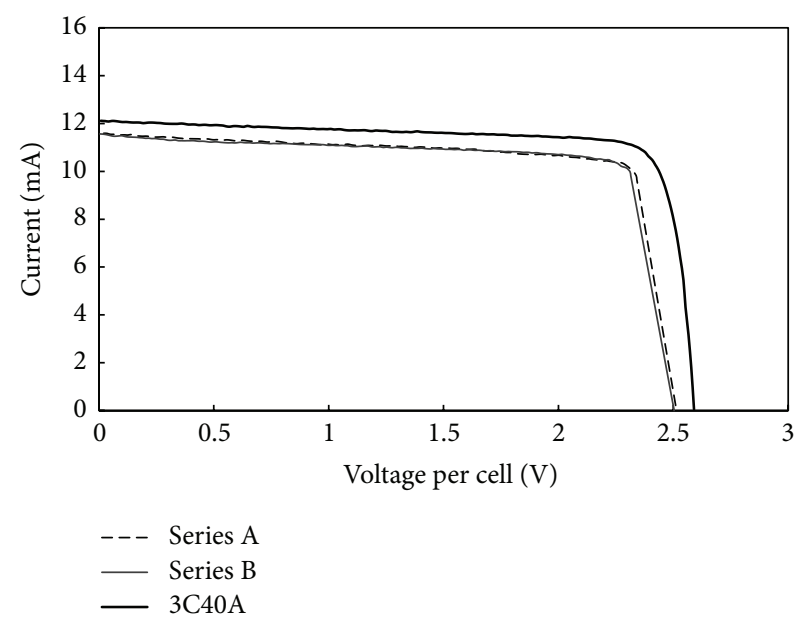

FIGURE 20: Comparison of the $I V$ curves of one of the cells mounted on the large cell assembly and that of the 3C40A single-cell receiver produced by AZUR SPACE. The curves are measured in the same conditions.

between the 144-cell plate and the single-cell receiver and by a potential nonuniformity in the solar simulator irradiance, which would affect only the larger assembly.

In a similar way, the maximum power point values can be predicted. At $500 \mathrm{x}$, each cell is expected to work at a maximum power point power of $14.7 \mathrm{~W}$, achieving, under $1000 \mathrm{~W} / \mathrm{m}^{2} \mathrm{DNI}$, an efficiency of $29.4 \%$. The commercial 
assembly instead reaches an efficiency of $31.9 \%$. The difference between the two efficiencies might be due to the dimensions of the tested boards.

The cell's datasheet reports a peak efficiency of $37.2 \%$ at $500 \mathrm{x}$, under standard test conditions. The characterization has been conducted at one sun, instead of at full 500x scale: the cells are designed to work at high concentrations, so they are expected to differently behave at one sun [56]. In particular, the cells used in this application are optimized for concentrations ranging between 300 and 500 suns [26]: the lack of concentration leads to a reduction in efficiency. For this reason, higher cell's efficiencies are expected to be achieved at full scale. Moreover, the discrepancy between the cell's and both the assemblies' efficiencies is probably partly due to the spectrum of the simulator, which is optimized for silicon cells, whereas it is less performing when triplejunction cells are tested.

In a real full-scale scenario, a combination of optical, mismatch, and Ohmic losses, along with the impacts of the temperature and the spectra, can occur and negatively affect the performances of the system [57]. The results of a full scale outdoor characterization will be presented in future works.

\section{Conclusions}

A new, densely packed assembly for 500x HCPV applications has been developed on an insulated metal substrate. For the first time, the design of a large, densely packed HCPV receiver has been detailed in a scientific paper. This assembly represents a novelty for the unique low-resistance design of the conductive layers. The application of IMS can represent a step ahead towards the awaited cost-cutting for HCPV. The receiver is designed to accommodate 144 cells and to work at a power output of $2.6 \mathrm{~kW}_{\mathrm{p}}$. Due to the large number of cells and the high concentration, the leading issues were to design a receiver able to handle the large waste heat generation thus maintaining high electrical properties and to assure long term reliability of the system. The geometry of all the components has been designed to fit the requirements of the standards and to grant acceptable thermal management and electrical performance to the assembly. The shape of the electrically conductive layer minimizes the electrical resistances, by reducing the number of interconnections, assuring easy scalability of the structure. The simple design can be used in different applications with few changes. All the assumptions and the analytical investigations made during the design stage have been reported. Schottky diodes have been used in the receiver to order to avoid damage to shaded cells and to reduce the power losses in case of current mismatch among different series-connected cells. The diodes are slightly oversized, consistent with the safety factors applied in commercial applications, in order to ensure better performance and a longer life to the device. Aluminium wires have been bonded to interconnect the cells and the conductive layers: they were sized to work safely even in the case of overcurrents caused by nonuniform irradiance over the cells. The reliability of the insulated metal substrates in the HCPV has been demonstrated using a software simulation: insulated metal substrates behave similarly to the more expensive direct bonded copper in terms of heat removal. The thermal behaviours have been proven using a 3D multiphysics simulation; the densely packed structure can be cooled using an active cooling system, even accounting for the Joule heating. The use of an IMS as the baseplate will help in experimentally understanding the potential and the weaknesses of this kind of substrates in HCPV applications. The prototype has been tested indoor for characterization, showing peak efficiency of $29.4 \%$ and a fill factor above $80 \%$. The developed assembly will be installed and tested in outdoor conditions: the results of a long-term outdoor characterization will be presented in future works.

\section{Nomenclature}

A: Area

$A_{w}:$ Cross-sectional area of the wire $\left(\mathrm{m}^{2}\right)$

cp: $\quad$ Specific heat capacity $(\mathrm{J} / \mathrm{K})$

$D_{w}$ : Diameter of the wire $(\mathrm{m})$

$f: \quad$ Focal length of the primary concentrator $(\mathrm{m})$

$h$ : Heat transfer coefficient $\mathrm{W} /\left(\mathrm{m}^{2} \mathrm{~K}\right)$

I: $\quad$ Current (A)

$k$ : Thermal conductivity $(\mathrm{W} / \mathrm{mK})$

$k_{B}$ : Boltzmann constant $(\mathrm{J} / \mathrm{K})$

$L: \quad$ Maximum geometric dimension $(\mathrm{mm})$

$l_{w}: \quad$ Length of the wire $(\mathrm{m})$

$n$ : Ideality factor

$N_{\text {cell }}$ : Number of cells

$N_{w}$ : Number of wires per cell

$q$ : Conduction heat flux $\left(\mathrm{W} / \mathrm{m}^{2}\right)$

$q_{\mathrm{el}}: \quad$ Elementary charge

$Q_{g}:$ Heat generated by the Joule losses (W)

$Q_{r}$ : Heat removed through conduction (W)

$Q_{v}^{\prime}$ : $\quad$ Volumetric heat source $\left(\mathrm{W} / \mathrm{m}^{3}\right)$

$R: \quad$ Electrical resistance $(\Omega)$

$R^{*}$ : Thermal resistance per unit of surface $\left(\mathrm{m}^{2} \mathrm{~K} / \mathrm{W}\right)$

$R: \quad$ Series resistance $(\Omega)$

T: $\quad$ Temperature $\left({ }^{\circ} \mathrm{C}\right)$

$t: \quad$ Thickness of the layer (m)

$V: \quad$ Voltage

$V_{\text {cell }}$ : Volume of the cell $\left(\mathrm{m}^{3}\right)$

$X$ : Concentrating Ratio.

Greek Symbols

$\alpha_{L}: \quad$ Coefficient of thermal expansion $\left(\mathrm{ppm} /{ }^{\circ} \mathrm{C}\right)$

$\Delta L:$ Deformation due to thermal expansion (mm)

$\Delta T_{c u}$ : Difference between the maximum operating temperature and the reference temperature of the copper layer $\left({ }^{\circ} \mathrm{C}\right)$

$\Delta T_{w}$ : Difference of temperature between the two ends of the wire $\left({ }^{\circ} \mathrm{C}\right)$

$\rho: \quad$ Electrical resistivity $(\Omega \mathrm{m})$

$\rho_{D}: \quad$ Density $\left(\mathrm{kg} / \mathrm{m}^{3}\right)$.

\section{Subscripts}

amb: Ambient 
$d$ : Downside surface of the layer

ext: External environment

$s$ : Surface

trl: Thin thermally resistive layer

$u$ : Upside surface of the layer

$w$ : Wire.

\section{Conflict of Interests}

The authors declare that there is no conflict of interests regarding the publication of this paper.

\section{Acknowledgments}

This work was financially supported by EPSRC-DST funded BioCPV project (EP/J000345/1). The authors would like to thank Cubik Innovation Ltd. and Custom Interconnect Ltd. for the assistance during the fabrication.

\section{References}

[1] M. Khamooshi, H. Salati, F. Egelioglu, A. H. Faghiri, J. Tarabishi, and S. Babadi, "A review of solar photovoltaic concentrators," International Journal of Photoenergy, vol. 2014, Article ID 958521, 17 pages, 2014

[2] F. Cotana, F. Rossi, and A. Nicolini, "Evaluation and optimization of an innovative low-cost photovoltaic solar concentrator," International Journal of Photoenergy, vol. 2011, Article ID 843209, 10 pages, 2011.

[3] K. Menoufi, D. Chemisana, and J. I. Rosell, "Life cycle assessment of a building integrated concentrated photovoltaic scheme," Applied Energy, vol. 111, pp. 505-514, 2013.

[4] S. Kurtz, "Opportunities and challenges for development of a mature concentrating photovoltaic power industry," Tech. Rep. NREL/TP-520-43208, 2009.

[5] E. F. Fernández, F. Almonacid, T. K. Mallick, and P. PérezHigueras, "Analytical modelling of high concentrator photovoltaic modules based on atmospheric parameters," International Journal of Photoenergy, vol. 2015, Article ID 872163, 8 pages, 2015.

[6] S. P. Philipps, A. W. Bett, K. Horowitz, and S. Kurtz, Current Status of Concentrator Photovoltaic (CPV) Technology, FraunhoferInstitut für Solare Energiesysteme ISE, Freiburg im Breisgau, Germany, 2015.

[7] M. A. Green, K. Emery, Y. Hishikawa, W. Warta, and E. D. Dunlop, "Solar cell efficiency tables (Version 45)," Progress in Photovoltaics: Research and Applications, vol. 23, no. 1, pp. 1-9, 2015.

[8] M. Yamaguchi, T. Takamoto, K. Araki, M. Imaizumi, N. Kojima, and Y. Ohshita, "Present and future of high efficiency multijunction solar cells," in Proceedings of the Conference on Lasers and Electro-Optics (CLEO '11), pp. 1-3, Baltimore, Md, USA, May 2011.

[9] IEEE-SA Standards Board, IEEE Recommended Practice for Qualification of Concentrator Photovoltaic (PV) Receiver Sections and Modules, IEEE, 2001.

[10] Spirit Circuits Limited, "Requirements of PCB's in solar \& LED applications," in Proceedings of the EIPC Winter Conference, 2013.

[11] M. Correvon, J. Nagashima, and R. Apter, "Power modules with IMS substrates for automotive applications," in Proceedings of the IEEE 55th Vehicular Technology Conference (VTC Spring '02), vol. 4, pp. 2056-2062, IEEE, 2002.

[12] L. Mabille, C. Mangeant, and M. Baudrit, "Development of CPV solar receiver based on insulated metal substrate (IMS): comparison with receiver based on the direct bonded copper substrate (DBC) - a reliability study," AIP Conference Proceedings, vol. 1477, pp. 289-293, 2012.

[13] A. Antonini, "Photovoltaic concentrators-fundamentals, applications, market \& prospective," in Solar Collectors and Panels, Theory and Applications, R. Manyala, Ed., chapter 2, pp. 31-54, InTech, Rijeka, Croatia, 2010.

[14] M. Cozzini, "Solar cell cooling and heat recovery in a concentrated photovoltaic system," in Proceedings of the European COMSOL Conference, Milano, Italy, 2012.

[15] I. Fishbein and N. M. Abramowitz, "Insulated metal substrates improve in performance and product implementation," in Proceedings of the 7th Annual Applied Power Electronics Conference and Exposition (APEC '92), pp. 633-638, IEEE, Boston, Mass, USA, February 1992.

[16] P. Mottier, "Frontmatter," in LED for Lighting Applications, Wiley-ISTE, 1st edition, 2010.

[17] AZUR SPACE Solar Power GmbH, Enhanced Fresnel Assembly-EFA, AZUR SPACE Solar Power GmbH, Heilbronn, Germany, 2010.

[18] Spectrolab Inc, CCA 100 C3MJ 1A Concentrator Cell Assembly, 91342, Spectrolab Inc, 2011.

[19] EMCORE Corporation, "CTJ Receiver Assembly-5.5 mm x $5.5 \mathrm{~mm}, " 617360,2011$.

[20] J. S. Foresi, L. Yang, P. Blumenfeld, J. Nagyvary, G. Flynn, and D. Aiken, "EMCORE receivers for CPV system development," in Proceedings of the 35th IEEE Photovoltaic Specialists Conference, pp. 209-212, IEEE, Honolulu, Hawaii, USA, 2010.

[21] K. Araki, P. Zamora, H. Nagai et al., "Design and development of $35 \%$ efficient and $1 \mathrm{X}$ CPV module with sufficient optical alignment tolerance," in Proceedings of the 38th IEEE Photovoltaic Specialists Conference (PVSC '12), pp. 1815-1819, IEEE, Austin, Tex, USA, June 2012.

[22] J. S. Foresi, L. Yang, P. Blumenfeld, J. Nagyvary, G. Flynn, and D. Aiken, "EMCORE receivers for CPV system development," in Proceedings of the 35th IEEE Photovoltaic Specialists Conference (PVSC '10), pp. 209-212, IEEE, Honolulu, Hawaii, USA, June 2010.

[23] M. Steiner, A. Bösch, A. Dilger et al., "FLATCON CPV module with $36.7 \%$ efficiency equipped with four-junction solar cells," Progress in Photovoltaics: Research and Applications, 2014.

[24] T. Mallick, N. Sarmah, S. Banerjee et al., "Design concept and configuration of a hybrid renewable energy system for rural electrification in India through BioCPV project," in Proceedings of the 4th International Conference on Advances in Energy Research, Mumbai, India, 2013.

[25] K. S. Reddy, S. Lokeswaran, P. Agarwal, and T. K. Mallick, "Numerical investigation of micro-channel based active module cooling for solar CPV system," Energy Procedia, vol. 54, pp. 400416, 2014.

[26] AZUR SPACE Solar Power GmbH, 3 C40 Concentrator Triple Junction Solar Cell Datasheet, AZUR SPACE Solar Power GmbH, Heilbronn, Germany, 2010.

[27] S. Silvestre, A. Boronat, and A. Chouder, "Study of bypass diodes configuration on PV modules," Applied Energy, vol. 86, no. 9, pp. 1632-1640, 2009. 
[28] F. J. Vorster and E. E. van Dyk, "Current-voltage characteristics of high-concentration, photovoltaic arrays," Progress in Photovoltaics: Research and Applications, vol. 13, no. 1, pp. 55-66, 2005.

[29] H. J. J. Janssen, P. J. Sonneveld, G. L. A. M. Swinkels, B. A. J. van Tuijl, H. F. de Zwart, and F. Dimroth, "The effect of shadow lines on a low concentrating photovoltaic system," in Proceedings of the 7th International Conference on Concentrating Photovoltaic Systems (CPV '11), pp. 150-153, Las Vegas, Nev, USA, April 2011.

[30] A. P. Malvino and D. J. Bates, Electronic Principles, McGrawHill, 2007.

[31] Ergon Solair, Ergonsolair HCPV modules—datasheet.

[32] K. A. McGowan, Semiconductors: From Book to Breadboard, Cengage Learning, Boston, Mass, USA, 1st edition, 2012.

[33] H. Cotal and J. Frost, "Heat transfer modeling of concentrator multijunction solar cell assemblies using finite difference techniques," in Proceedings of the 35th IEEE Photovoltaic Specialists Conference (PVSC '10), pp. 000213-000218, IEEE, Honolulu, Hawaii, USA, June 2010.

[34] A. F. A. Mills, Basic Heat and Mass Transfer, Prentice Hall, London, UK, 2nd edition, 1999.

[35] I. Barducci, Trasmissione del Calore, Masson Editoriale ESA, Rome, Italy, 1995.

[36] F. P. Incropera, D. P. DeWitt, T. L. Bergman, and A. S. Lavine, Fundamentals of Heat and Mass Transfer, Wiley, 2007.

[37] Y. A. Çengel, Introduction to Thermodynamics and Heat Transfer, McGraw-Hill, 2nd edition, 2008.

[38] L. Micheli, N. Sarmah, X. Luo, K. S. Reddy, and T. K. Mallick, "Design of a 16-cell densely-packed receiver for high concentrating photovoltaic applications," Energy Procedia, vol. 54, pp. 185-198, 2014.

[39] G. Martinelli and M. Stefancich, "7 Solar cell cooling," in Concentrator Photovoltaics, pp. 133-149, Springer, 2007.

[40] L. Micheli, N. Sarmah, X. Luo, K. S. Reddy, and T. K. Mallick, "Development of a novel 16-cell densely packed 500x CPV assembly on insulated metal substrate," in Proceedings of the 4th International Conference on Advances in Energy Research, P. Ghosh, Ed., pp. 948-956, Mumbai, India, December 2013.

[41] A. Royne, C. J. Dey, and D. R. Mills, "Cooling of photovoltaic cells under concentrated illumination: a critical review," Solar Energy Materials and Solar Cells, vol. 86, no. 4, pp. 451-483, 2005.

[42] G. S. Kinsey and K. M. Edmondson, "Spectral response and energy output of concentrator multijunction solar cells," Progress in Photovoltaics: Research and Applications, vol. 17, no. 5, pp. 279-288, 2009.

[43] E. F. Fernández, F. Almonacid, P. Rodrigo, and P. PérezHigueras, "Calculation of the cell temperature of a high concentrator photovoltaic (HCPV) module: a study and comparison of different methods," Solar Energy Materials and Solar Cells, vol. 121, pp. 144-151, 2014.

[44] IEC, "Concentrator photovoltaic (CPV) module and assembly performance testing and energy rating-part 1: performance measurements and power rating-irradiance and temperature," IEC 62670-1, 2012.

[45] M. Muller, C. Deline, B. Marion, and S. Kurtz, "Determining outdoor CPV cell temperature," in Proceedings of the 7th International Conference on Concentrating Photovoltaic Systems (CPV '11), Las Vegas, Nev, USA, April 2011.

[46] IPC-Association Connecting Electronics Industries, "Generic standard on printed board design," IPC-2221, 1998.
[47] L. Micheli, N. Sarmah, X. Luo, K. S. Reddy, and T. K. Mallick, "Design and production of a $2.5 \mathrm{kWe}$ insulated metal substratebased densely packed CPV assembly," AIP Conference Proceedings, vol. 1616, pp. 196-199, 2014.

[48] M. L. Minges, Electronic Materials Handbook: Vol 1, Packaging, CRC Press, 1989.

[49] J. Shah, "Estimating bond wire current-carrying capacity," Tech. Rep., Power Systems Design, 2012.

[50] H. Baig, K. C. Heasman, and T. K. Mallick, "Non-uniform illumination in concentrating solar cells," Renewable and Sustainable Energy Reviews, vol. 16, no. 8, pp. 5890-5909, 2012.

[51] P. Sharma, A. W. Walker, J. F. Wheeldon, K. Hinzer, and H. Schriemer, "Enhanced efficiencies for high-concentration, multijunction PV systems by optimizing grid spacing under nonuniform illumination," International Journal of Photoenergy, vol. 2014, Article ID 582083, 7 pages, 2014.

[52] Bergquist Company, Baseplate Design Considerations, (n.d.) 12-13.

[53] EKO Instruments, MP-160 I-V Curve Tracer Instruction Manual, EKO Instruments, 2009.

[54] G. S. Kinsey, P. Hebert, K. E. Barbour, D. D. Krut, H. L. Cotal, and R. A. Sherif, "Concentrator multijunction solar cell characteristics under variable intensity and temperature," Progress in Photovoltaics: Research and Applications, vol. 16, no. 6, pp. 503-508, 2008.

[55] M. Data, T. Average, and E. Data, "Enhanced Fresnel Assembly-EFA Cell Type: Concentrator Triple Junction Solar Cell3C40A Application: Concentrating Photovoltaic COC Assembly," 3-6, 2012.

[56] E. F. Fernández, A. J. G. Loureiro, and G. P. Smestad, "Multijunction concentrator solar cells: analysis and fundamentals," in High Concentrator Photovoltaics. Fundamentals, Engineering and Power Plants, P. Pérez-Higueras and E. F. Fernández, Eds., Springer, 2015.

[57] E. F. Fernández, G. Siefer, F. Almonacid, A. J. G. Loureiro, and P. Pérez-Higueras, "A two subcell equivalent solar cell model for III-V triple junction solar cells under spectrum and temperature variations," Solar Energy, vol. 92, pp. 221-229, 2013. 

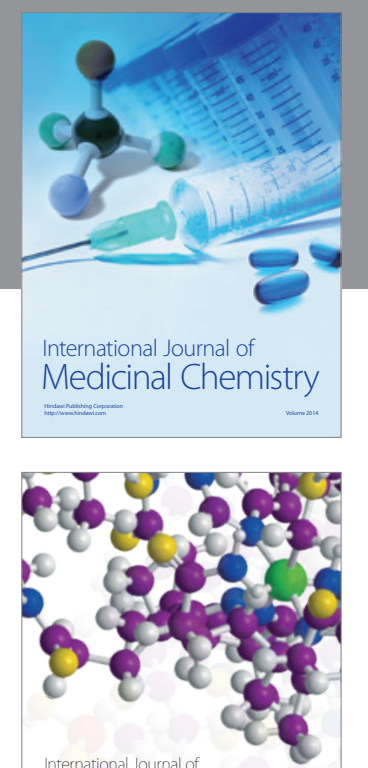

\section{Carbohydrate} Chemistry

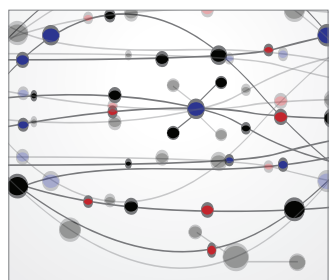

The Scientific World Journal
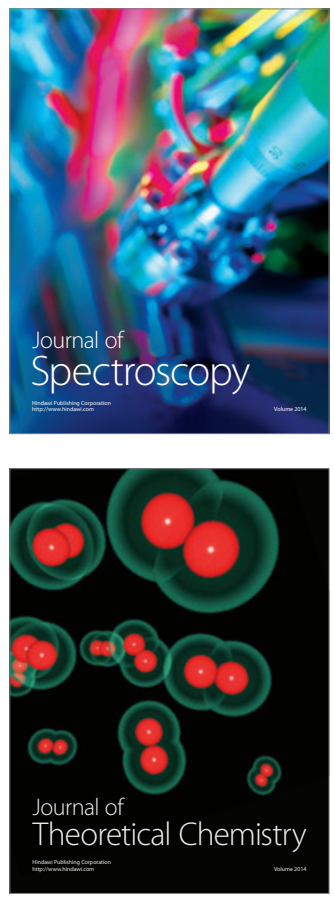
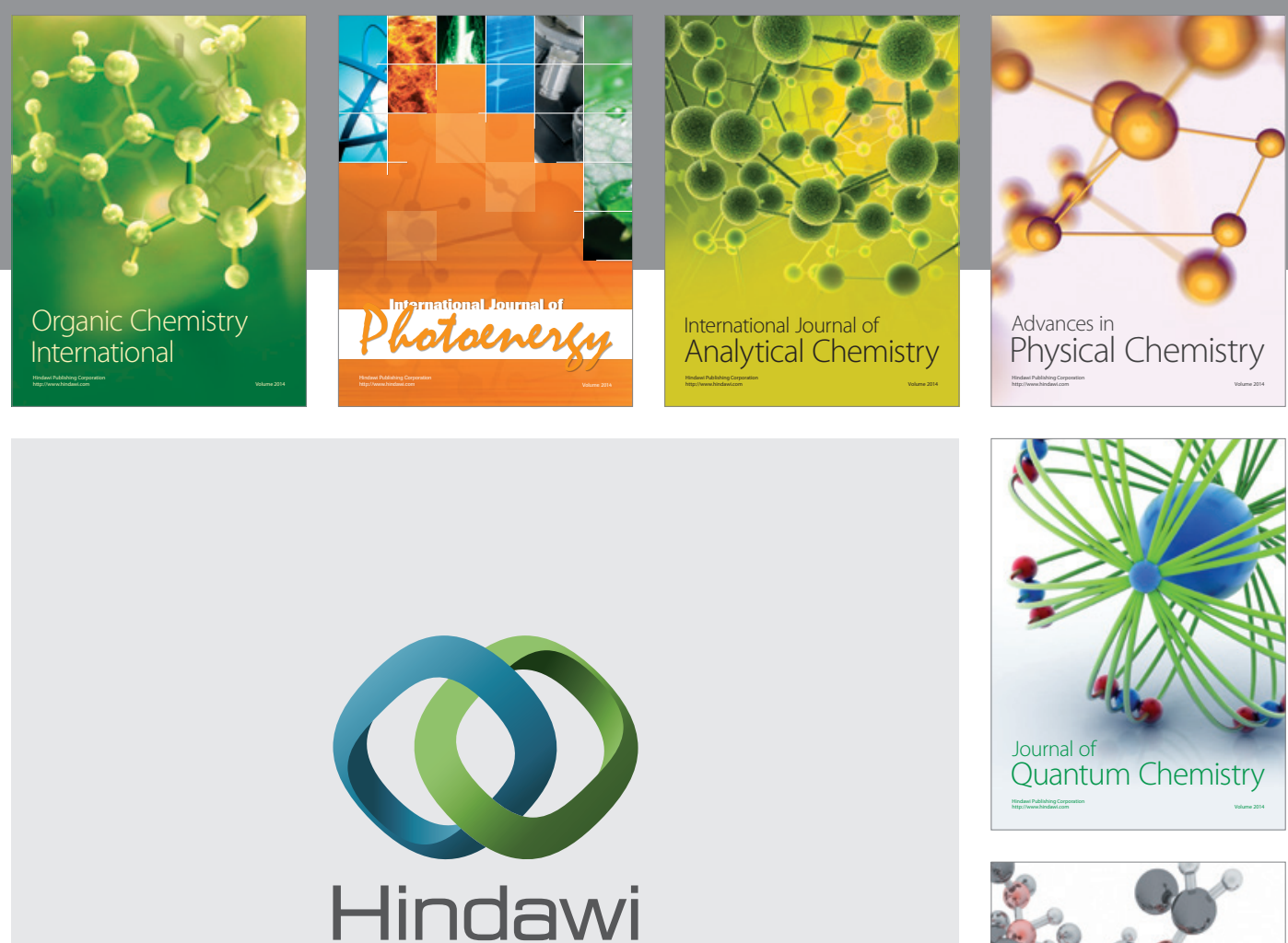

Submit your manuscripts at

http://www.hindawi.com

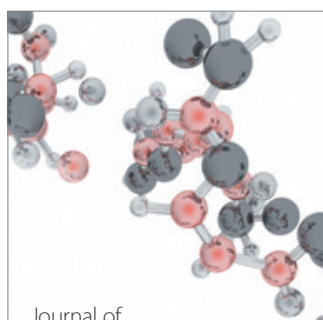

Analytical Methods

in Chemistry

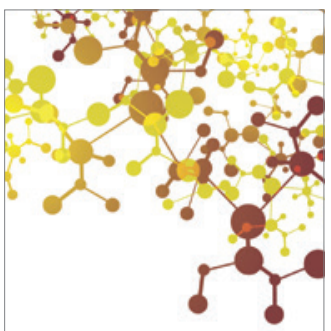

Journal of

Applied Chemistry

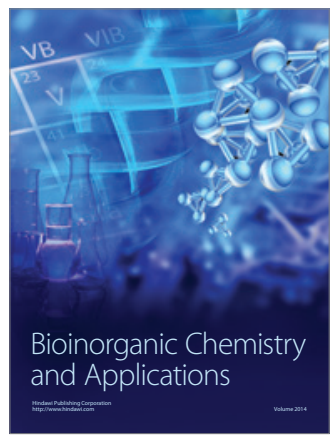

Inorganic Chemistry
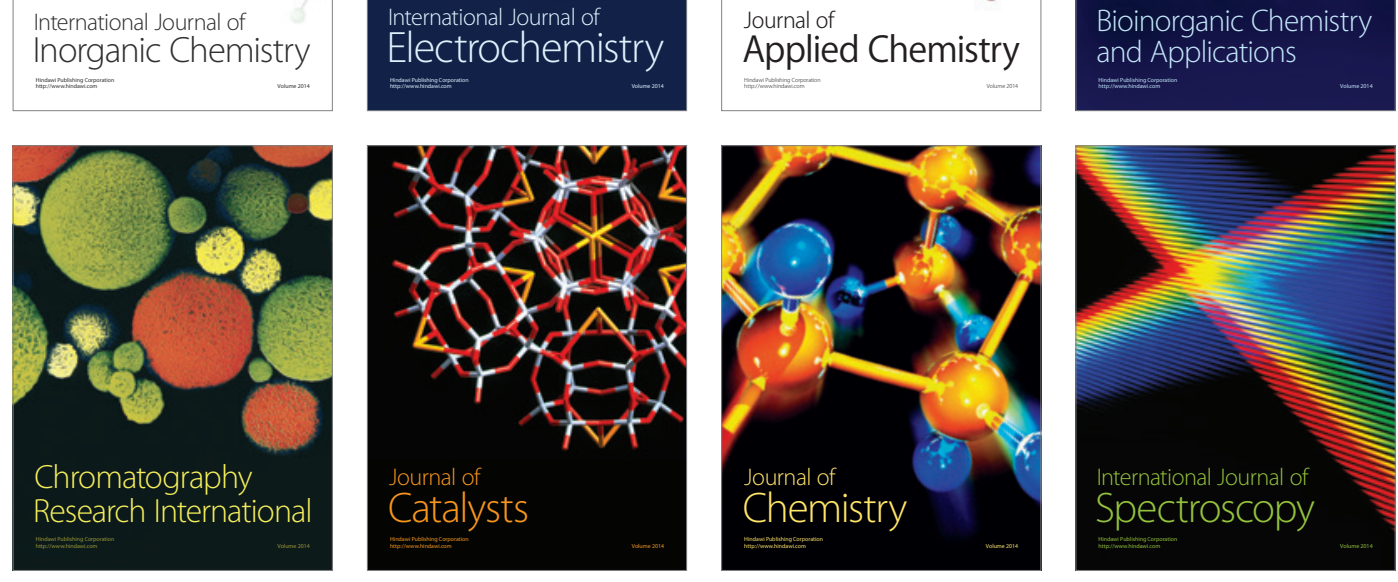